\title{
Current State of Research on the Risk of Morbidity and Mortality Associated with Air Pollution in Korea
}

\author{
Sanghyuk Bae ${ }^{1}$ and Ho-jang Kwon ${ }^{2}$ \\ ${ }^{1}$ Department of Preventive Medicine, College of Medicine, The Catholic University of Korea, Seoul; \\ ${ }^{2}$ Department of Preventive Medicine, Dankook University College of Medicine, Cheonan, Korea.
}

Purpose: The effects of air pollution on health can vary regionally. Our goal was to comprehensively review previous epidemiological studies on air pollution and health conducted in Korea to identify future areas of potential study.

Materials and Methods: We systematically searched all published epidemiologic studies examining the association between air pollution and occurrence of death, diseases, or symptoms in Korea. After classifying health outcomes into mortality, morbidity, and health impact, we summarized the relationship between individual air pollutants and health outcomes.

Results: We analyzed a total of 27 studies that provided 104 estimates of the quantitative association between risk of mortality and exposure to air pollutants, including particulate matter with aerodynamic diameter less than $10 \mu \mathrm{m}$, particulate matter with aerodynamic diameter less than $2.5 \mu \mathrm{m}$, sulfur dioxide, nitrogen dioxide, ozone, and carbon monoxide in Korea between January 1999 and July 2018. Regarding the association with morbidity, there were 38 studies, with 98 estimates, conducted during the same period. Most studies examined the short-term effects of air pollution using a time series or case-crossover study design; only three cohort studies that examined long-term effects were found. There were four health impact studies that calculated the attributable number of deaths or disability-adjusted life years due to air pollution.

Conclusion: There have been many epidemiologic studies in Korea regarding air pollution and health. However, the present review shows that additional studies, especially cohort and experimental studies, are needed to provide more robust and accurate evidence that can be used to promote evidence-based policymaking.

Key Words: Air pollution, mortality, morbidity, environmental medicine, Korea

\section{INTRODUCTION}

The effect of air pollution on mortality and the burden of disease increases as air pollution increases, although estimates can vary from region to region. According to the Global Burden of Disease Study, ambient air pollution accounted for $7.5 \%$ of deaths globally in 2016 and was the sixth leading contributor to attributable disability-adjusted life years (DALYs) in that

Received: November 27, 2018

Corresponding author: $\mathrm{Ho}$-jang Kwon, MD, PhD, Department of Preventive Medicine, Dankook University College of Medicine, 119 Dandae-ro, Dongnam-gu, Cheonan 31116 , Korea.

Tel: 82-41-550-3879, Fax: 82-41-556-6461, E-mail: hojang@dankook.ac.kr

-The authors have no potential conflicts of interest to disclose.

(C) Copyright: Yonsei University College of Medicine 2019

This is an Open Access article distributed under the terms of the Creative Commons Attribution Non-Commercial License (https://creativecommons.org/licenses/ by-nc/4.0) which permits unrestricted non-commercial use, distribution, and reproduction in any medium, provided the original work is properly cited. year. ${ }^{1}$ Korea has experienced rapid economic growth in the last century, and the quality of the atmosphere has worsened. Air pollution reduction policies, such as the Special Law on Air Quality in the Seoul metropolitan area, have had limited effect on particulate matter (PM) pollution, and the overall air quality remains poor. Concentrations of $\mathrm{PM}$ with aerodynamic diameter less than $10 \mu \mathrm{m}\left(\mathrm{PM}_{10}\right)$ have improved over the past decade, reaching the lowest national average of $45 \mu \mathrm{g} / \mathrm{m}^{3}$ in 2012 , and then rebounding to a level of $47 \mu \mathrm{g} / \mathrm{m}^{3}$ in 2016. However, the concentration of nitrogen dioxide $\left(\mathrm{NO}_{2}\right)$ has remained relatively constant, with no large changes. The average values of ozone $\left(\mathrm{O}_{3}\right)$ concentration are continuously increasing. ${ }^{2}$

Epidemiological studies on the health effects of air pollution have been actively conducted in many countries. In particular, time series studies to examine the short-term effects of air pollution have been conducted worldwide and have yielded relatively consistent results. ${ }^{3,4}$ However, cohort studies to assess the long-term effects of air pollution have been primar- 
ily conducted in Western countries that have relatively low concentrations of air pollutants. Due to a lack of direct evidence at higher global concentrations, the integrated expose-response (IER) model was developed. The IER combines information on PM-mortality associations from non-outdoor sources, including secondhand smoke, active smoking, and household air pollution, ${ }^{5}$ and has been used to estimate the disease burden attributable to PM with aerodynamic diameter less than $2.5 \mu \mathrm{m}\left(\mathrm{PM}_{2.5}\right){ }^{1}{ }^{1}$ As the use of IER requires a strict assumption of equal toxicity per unit dose across these non-outdoor sources, cohort studies are needed that reflect the different air pollution concentrations in different regions. ${ }^{6}$

The health effects of air pollution can vary regionally depending on the composition of pollutants or characteristics of the population at risk. The regional differences in $\mathrm{PM}_{2.5}$ mortality risk estimates can likely be attributed to geographic variation in particle composition or the spatial heterogeneity of constituents, ${ }^{7}$ as well as differences in the total air pollution mixture. ${ }^{8}$ Regional differences of topography, which may lead to regional differences of exposure error, can contribute to regional differences in PM risk estimates. ${ }^{9}$

To accurately understand the impact of air pollution on health in Korea, the results of research performed specifically for Korea are needed. Since the publication of time series research starting in 1999 in Korea, ${ }^{10}$ many epidemiological studies have been conducted; however, the results of these studies have not been systematically summarized. To accurately assess the impact of air pollution in Korea and to clarify future research directions, systematic sorting of epidemiological studies on air pollution conducted in Korea is required. The aim of the present analysis was to comprehensively review previous epidemiological studies on air pollution and health conducted in Korea to identify future study needs.

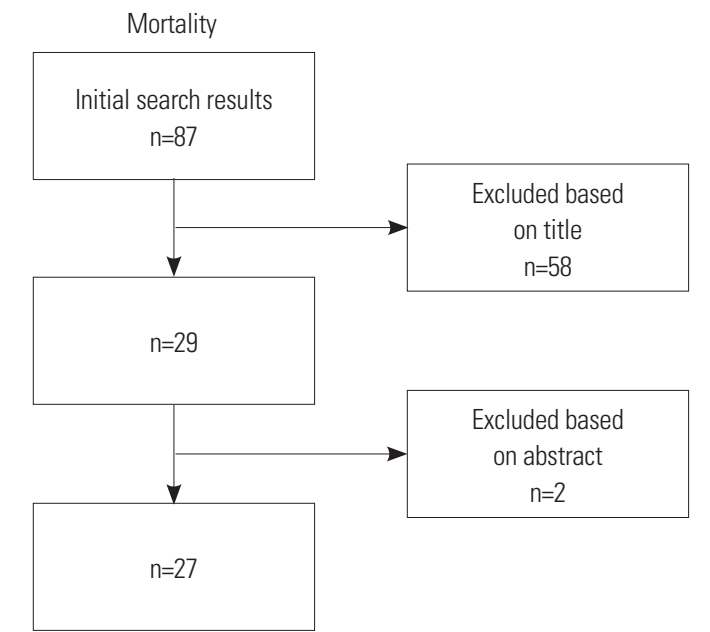

\section{LITERATURE SEARCH}

We conducted a literature search in PubMed using the search terms ("air pollution"[MeSH Terms] OR ("air"[All Fields] AND "pollution"[All Fields]) OR "air pollution"[All Fields]) AND ("mortality"[Subheading] OR "mortality"[All Fields] OR "mortality"[MeSH Terms]) AND ("Korea"[MeSH Terms] OR "Korea"[All Fields]) and (("air pollution"[MeSH Terms] OR ("air"[All Fields] AND "pollution"[All Fields]) OR "air pollution" [All Fields]) AND ("epidemiology"[Subheading] OR "epidemiology" [All Fields] OR "morbidity"[All Fields] OR "morbidity" [MeSH Terms]) AND ("Korea”[MeSH Terms] OR "Korea"[All Fields])) NOT ("mortality"[Subheading] OR "mortality" [MeSH Terms]) to find published studies on the associations of air pollution with mortality and morbidity respectively in Korea, between January 1990 and July 2018.

We also searched for health impact assessment studies using the same search engine and the search terms ("number" [All Fields] AND ("death"[MeSH Terms] OR "death"[All Fields] OR "deaths"[All Fields])) OR "burden of disease"[All Fields] OR "health impact assessment"[All Fields] AND "Korea"[All Fields] AND ("air pollution"[All Fields] OR "ambient"[All Fields]).

After reviewing the title and abstract of each article, we selected epidemiological studies that reported associations between exposure to air pollution and mortality or morbidity. We then summarized these articles according to their characteristics and results.

The initial search for mortality and morbidity returned 87 and 195 results, respectively. After excluding articles that did not meet the inclusion criteria (Fig. 1), there remained 27 (Table 1) and 37 studies (Table 2) on mortality and morbidity, respectively. One of the mortality study also reported morbidity results, so a total of 38 studies were included in the present review. The search for health impact analyses returned 22 studies; four articles remained after a review of titles and abstracts.

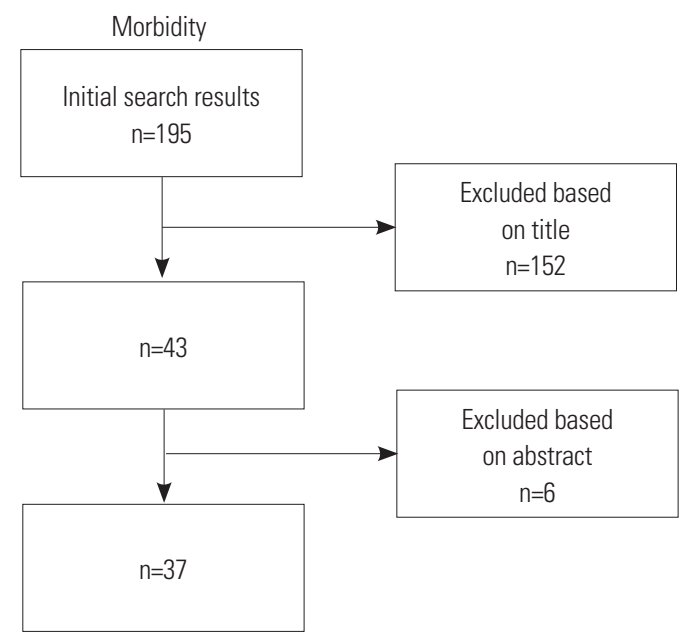

Fig. 1. Selection of papers. 
Sanghyuk Bae and Ho-jang Kwon

Table 1. Epidemiological Studies on Air Pollution and Mortality in Korea between 1999 and 2018

\begin{tabular}{|c|c|c|c|c|c|c|c|c|}
\hline No. & Author (year) & Study design & Study period & Location & Outcome & Pollutant & Unit & Effect size \\
\hline \multirow{6}{*}{1} & \multirow{6}{*}{ Lee, et al. $(1999)^{10}$} & \multirow{6}{*}{ Time series } & \multirow{6}{*}{ 1991-1995 } & Seoul & Non-accidental & $\mathrm{SO}_{2}$ & $50 \mathrm{ppb}$ & RR $1.078(1.057,1.099)$ \\
\hline & & & & Ulsan & Non-accidental & $\mathrm{SO}_{2}$ & 50 ppb & RR 1.051 (0.991, 1.115) \\
\hline & & & & Seoul & Non-accidental & TSP & $100 \mu \mathrm{g} / \mathrm{m}^{3}$ & RR $1.051(1.031,1.072)$ \\
\hline & & & & Ulsan & Non-accidental & TSP & $100 \mu \mathrm{g} / \mathrm{m}^{3}$ & RR 0.999 (0.961, 1.039) \\
\hline & & & & Seoul & Non-accidental & $1 \mathrm{hr} \max \mathrm{O}_{3}$ & 50 bbp & RR $1.015(1.005,1.025)$ \\
\hline & & & & Ulsan & Non-accidental & $1 \mathrm{hr} \max \mathrm{O}_{3}$ & 50 bbp & RR $1.020(0.889,1.170)$ \\
\hline \multirow{2}{*}{2} & \multirow{2}{*}{ Hong, et al. (1999) } & \multirow{2}{*}{ Time series } & \multirow{2}{*}{1995} & \multirow{2}{*}{ Incheon } & Total & TSP & $10 \mu \mathrm{g} / \mathrm{m}^{3}$ & $1.2 \%(0.2,2.2)$ \\
\hline & & & & & Total & $\mathrm{PM}_{10}$ & $10 \mu \mathrm{g} / \mathrm{m}^{3}$ & $1.2 \%(0.2,2.1)$ \\
\hline \multirow{3}{*}{3} & \multirow{3}{*}{ Lee, et al. (1999)12 } & \multirow{3}{*}{ Case-crossover } & & \multirow{3}{*}{ Seoul } & Non-accidental & $\mathrm{SO}_{2}$ & $50 \mathrm{ppb}$ & RR $1.023(1.016,1.084)$ \\
\hline & & & & & Non-accidental & Maximum $\mathrm{O}_{3}$ & $50 \mathrm{ppb}$ & RR $1.023(0.999,1.048)$ \\
\hline & & & & & Non-accidental & TSP & $100 \mu \mathrm{g} / \mathrm{m}^{3}$ & RR $1.010(0.988,1.032)$ \\
\hline \multirow{5}{*}{4} & \multirow{5}{*}{ Hong, et al. (1999)11 } & \multirow{5}{*}{ Time series } & \multirow{5}{*}{ 1995-1996 } & \multirow{5}{*}{ Incheon } & Total & $\mathrm{PM}_{10}$ & $10 \mu \mathrm{g} / \mathrm{m}^{3}$ & RR 1.007 (1.001, 1.0013) \\
\hline & & & & & Total & $\mathrm{NO}_{2}$ & & RR $1.0026(1.0006,1.0046)$ \\
\hline & & & & & Total & $\mathrm{SO}_{2}$ & & RR $1.0023(0.9996,1.0051)$ \\
\hline & & & & & Total & $\mathrm{CO}$ & & RR $1.0019(0.9990,1.0049)$ \\
\hline & & & & & Total & $\mathrm{O}_{3}$ & & RR $0.9951(0.9908,0.9994)$ \\
\hline \multirow{2}{*}{5} & \multirow{2}{*}{ Lee, et al. $(2000)^{59}$} & \multirow{2}{*}{ Time series } & \multirow{2}{*}{ 1991-1997 } & & Total & TSP & $100 \mu \mathrm{g} / \mathrm{m}^{3}$ & $0.5-4 \%$ \\
\hline & & & & / cities & Total & $\mathrm{SO}_{2}$ & $50 \mathrm{ppb}$ & RR $1.03(1.01,1.05)$ \\
\hline & & & & & Total & $\mathrm{PM}_{10}$ & $\operatorname{IQR}\left(42.1 \mu \mathrm{g} / \mathrm{m}^{3}\right)$ & OR $1.014(1.006,1.022)$ \\
\hline & & & & & Total & $\mathrm{CO}$ & IQR (0.59 ppm) & OR $1.022(1.017,1.029)$ \\
\hline 6 & Kwon, et al. $(2001)^{20}$ & Time series & 1994-1998 & Seoul & Total & $\mathrm{NO}_{2}$ & IQR (14.6 ppb) & OR $1.021(1.014,1.029)$ \\
\hline & & & & & Total & $\mathrm{SO}_{2}$ & IQR (9.9 ppb) & OR $1.020(1.012,1.028)$ \\
\hline & & & & & Total & $\mathrm{O}_{3}$ & IOR (20.5 ppb) & OR $1.010(1.002,1.017)$ \\
\hline & & & & & Stroke & $\mathrm{PM}_{10}$ & IOR & $1.5 \%(1.3,1.8)$ \\
\hline & & & & & Stroke & $\mathrm{O}_{3}$ & IOR & $2.9 \%(0.3,5.5)$ \\
\hline 7 & Hong, et al. $(2002)^{60}$ & Time series & 1995-1998 & Seoul & Stroke & $\mathrm{NO}_{2}$ & IOR & $3.1 \%(1.1,5.1)$ \\
\hline & & & & & Stroke & $\mathrm{SO}_{2}$ & IOR & $2.9 \%(0.8,5.0)$ \\
\hline & & & & & Stroke & $\mathrm{CO}$ & IOR & $4.1 \%(1.1,7.2)$ \\
\hline & & & & & Ischemic stroke & TSP & IOR & RR $1.03(1.00,1.06)$ \\
\hline & & & & & Ischemic stroke & $\mathrm{SO}_{2}$ & IOR & RR $1.04(1.01,1.08)$ \\
\hline 8 & Hong, et al. $(2002)^{21}$ & Time series & 1991-1997 & Seoul & Ischemic stroke & $\mathrm{NO}_{2}$ & IOR & RR $1.04(1.01,1.07)$ \\
\hline & & & & & Ischemic stroke & $\mathrm{CO}$ & IQR & RR $1.06(1.02,1.09)$ \\
\hline & & & & & Ischemic stroke & $\mathrm{O}_{3}$ & IQR & RR $1.06(1.02,1.10)$ \\
\hline & & & & & Total (postneonates) & $\mathrm{PM}_{10}$ & $\operatorname{IQR}\left(42.9 \mu \mathrm{g} / \mathrm{m}^{3}\right)$ & RR $1.142(1.096,1.190)$ \\
\hline 9 & Ha, et al. $(2003)^{61}$ & Cohort & & & $\begin{array}{l}\text { Respiratory } \\
\text { (postneonates) }\end{array}$ & $\mathrm{PM}_{10}$ & $\operatorname{IOR}\left(42.9 \mu \mathrm{g} / \mathrm{m}^{3}\right)$ & RR $2.018(1.784,2.283)$ \\
\hline & & & & & Non-accidental & $\mathrm{PM}_{10}$ & IOR $\left(43.12 \mu \mathrm{g} / \mathrm{m}^{3}\right)$ & $3.7 \%(2.1,5.4)$ \\
\hline & & & & & Respiratory & $\mathrm{PM}_{10}$ & IQR $\left(43.12 \mu \mathrm{g} / \mathrm{m}^{3}\right)$ & $13.9 \%(6.8,21.5)$ \\
\hline 10 & Kım, et al. (2003) & lıme serıes & 199b-1999 & Seoul & Cardiovascular & $\mathrm{PM}_{10}$ & IOR $\left(43.12 \mu \mathrm{g} / \mathrm{m}^{3}\right)$ & $4.4 \%(-1.0,9.0)$ \\
\hline & & & & & Cerebrovascular & $\mathrm{PM}_{10}$ & IOR $\left(43.12 \mu \mathrm{g} / \mathrm{m}^{3}\right)$ & $6.3 \%(2.3,10.5)$ \\
\hline & & & & & Non-accidental & $\mathrm{PM}_{10}$ (mean) & $\operatorname{IOR}\left(42.11 \mu \mathrm{g} / \mathrm{m}^{3}\right)$ & RR 1.021 (1.009, 1.035) \\
\hline 11 & Kim, et al. $(2004)^{22}$ & lıme serıes & 199/-2004 & Seoul & Non-accidental & $\mathrm{PM}_{10}(\mathrm{SD})$ & $\operatorname{IOR}\left(11.93 \mu \mathrm{g} / \mathrm{m}^{3}\right)$ & RR $1.025(1.000,1.028)$ \\
\hline 12 & Lee, et al. $(2007)^{63}$ & Time series & 2000-2004 & Seoul & Non-accidental & $\begin{array}{l}\text { Asian dust } \\
\text { event }\end{array}$ & & $\begin{array}{l}\text { Larger effect sizes in the } \\
\text { model without Asian dust } \\
\text { event }\end{array}$ \\
\hline & & & & & Respiratory & $\begin{array}{l}\text { Fine particle } \\
\text { count }\end{array}$ & $\begin{array}{l}\text { IOR }(10.221 \\
\left.\text { number } / \mathrm{cm}^{3}\right)\end{array}$ & $5.73 \%(5.03,6.45)$ \\
\hline 13 & Cho, et al. $(2008)^{44}$ & lıme serıes & 2001 & Seoul & Respiratory & $\begin{array}{l}\text { Respiratory } \\
\text { particle count }\end{array}$ & $\begin{array}{l}\text { IOR }(10.38 \\
\left.\text { number } / \mathrm{cm}^{3}\right)\end{array}$ & $5.82 \%(5.13,6.53)$ \\
\hline
\end{tabular}


Table 1. Epidemiological Studies on Air Pollution and Mortality in Korea between 1999 and 2018 (Continued)

\begin{tabular}{|c|c|c|c|c|c|c|c|c|}
\hline No. & Author (year) & Study design & Study period & Location & Outcome & Pollutant & Unit & Effect size \\
\hline \multirow{5}{*}{14} & \multirow{5}{*}{ Son, et al. $(2008)^{22}$} & \multirow{5}{*}{ Case-crossover } & \multirow{5}{*}{ 1999-2003 } & \multirow{5}{*}{ Seoul } & Infant & $\mathrm{PM}_{10}$ & $1 \mu \mathrm{g} / \mathrm{m}^{3}$ & OR $1.000(0.998,1.002)$ \\
\hline & & & & & Infant & $\mathrm{NO}_{2}$ & 1 unit & OR $1.002(0.994,1.009)$ \\
\hline & & & & & Infant & $\mathrm{SO}_{2}$ & 1 unit & OR $1.015(0.973,1.058)$ \\
\hline & & & & & Infant & $\mathrm{CO}$ & 1 unit & OR $1.029(0.833,1.271)$ \\
\hline & & & & & Infant & $\mathrm{O}_{3}$ & 1 unit & OR $0.984(0.977,0.992)$ \\
\hline \multirow{3}{*}{15} & \multirow{3}{*}{ Yi, et al. $(2010)^{75}$} & \multirow{3}{*}{ Case-crossover } & \multirow{3}{*}{ 2000-2006 } & \multirow{3}{*}{ Seoul } & Non-accidental & $\mathrm{PM}_{10}$ & $10 \mu \mathrm{g} / \mathrm{m}^{3}$ & $0.28 \%(0.12,0.44)$ \\
\hline & & & & & Cardiovascular & $\mathrm{PM}_{10}$ & $10 \mu \mathrm{g} / \mathrm{m}^{3}$ & $0.51 \%(0.19,0.83)$ \\
\hline & & & & & Respiratory & $\mathrm{PM}_{10}$ & $10 \mu \mathrm{g} / \mathrm{m}^{3}$ & $0.59 \%(-0.08,1.26)$ \\
\hline \multirow{2}{*}{16} & \multirow{2}{*}{ Kim, et al. $(2010)^{19}$} & \multirow{2}{*}{ Case-crossover } & \multirow{2}{*}{2004} & \multirow{2}{*}{7 cities } & Suicide & $\mathrm{PM}_{10}$ & IOR & $9.0 \%(2.4,16.1)$ \\
\hline & & & & & Suicide & $\mathrm{PM}_{2.5}$ & IQR & $10.1 \%(2.0,19.0)$ \\
\hline \multirow{2}{*}{17} & \multirow{2}{*}{ Park, et al. $(2011)^{65}$} & \multirow{2}{*}{ Time-series } & \multirow{2}{*}{ 1999-2007 } & \multirow{2}{*}{ Seoul } & $\begin{array}{l}\text { Non-accidental } \\
\text { (high temp. } \\
\geq 26.2^{\circ} \mathrm{C} \text { ) }\end{array}$ & $\mathrm{SO}_{2}$ & $0.5 \mathrm{ppb}$ & $0.83 \%(0.42,1.25)$ \\
\hline & & & & & $\begin{array}{l}\text { Non-accidental } \\
\text { (low temp. } \\
<26.2^{\circ} \mathrm{C} \text { ) }\end{array}$ & $\mathrm{SO}_{2}$ & $0.5 \mathrm{ppb}$ & $0.21 \%(0.07,0.36)$ \\
\hline \multirow{8}{*}{18} & \multirow{8}{*}{ Son, et al. $(2011)^{66}$} & \multirow{8}{*}{ Birth cohort } & \multirow{8}{*}{ 2004-2007 } & & All-cause infant & TSP & IOR & HR $1.44(1.06,1.97)$ \\
\hline & & & & & All-cause infant & $\mathrm{PM}_{10}$ & IOR & HR $1.65(1.18,2.31)$ \\
\hline & & & & & All-cause infant & $\mathrm{PM}_{2.5}$ & IQR & HR $1.53(1.22,1.90)$ \\
\hline & & & & Senul & All-cause infant & $\mathrm{PM}_{10-2.5}$ & IQR & HR $1.19(0.83,1.70)$ \\
\hline & & & & seoul & Respiratory infant & TSP & IQR & HR $3.78(1.18,12.13)$ \\
\hline & & & & & Respiratory infant & $\mathrm{PM}_{10}$ & IQR & HR $6.20(1.50,25.66)$ \\
\hline & & & & & Respiratory infant & $\mathrm{PM}_{2.5}$ & IOR & HR $3.15(1.26,7.85)$ \\
\hline & & & & & Respiratory infant & $\mathrm{PM}_{10-2.5}$ & IQR & HR $2.86(0.76,10.85)$ \\
\hline & & & & & Total & $\mathrm{PM}_{10}$ & IOR & $0.94 \%(0.25,1.62)$ \\
\hline & & & & & Total & $\mathrm{NO}_{2}$ & IQR & $2.27 \%(1.03,3.53)$ \\
\hline & & & & & Total & $\mathrm{SO}_{2}$ & IOR & $1.94 \%(0.80,3.09)$ \\
\hline & & & & & Total & $\mathrm{CO}$ & IOR & $2.21 \%(1.00,3.43)$ \\
\hline 19 & Son et al 12012$)^{14}$ & & & & Total & $\mathrm{O}_{3}$ & IQR & Positive/NS \\
\hline 19 & son, et al. $(\angle U \mid Z)^{-}$ & lase-crossover & $\angle O U O-\angle O U \prime$ & seoul & Cardiovascular & $\mathrm{PM}_{10}$ & IQR & $1.95 \%(0.64,3.27)$ \\
\hline & & & & & Cardiovascular & $\mathrm{NO}_{2}$ & IQR & $4.82 \%(2.18,7.54)$ \\
\hline & & & & & Cardiovascular & $\mathrm{SO}_{2}$ & IQR & $3.64 \%(1.46,5.87)$ \\
\hline & & & & & Cardiovascular & $\mathrm{CO}$ & IOR & $4.32 \%(1.77,6.92)$ \\
\hline & & & & & Cardiovascular & $\mathrm{O}_{3}$ & IOR & Positive/NS \\
\hline 20 & Heo, et al. $(2014)^{67}$ & Time-series & 2003-2007 & Seoul & $\begin{array}{l}\text { Non-accidental, } \\
\text { cardiovascular, } \\
\text { respiratory }\end{array}$ & $\begin{array}{l}\mathrm{PM}_{2.5} \text { and } \\
\text { components }\end{array}$ & & $\begin{array}{l}\text { Percentage of excess risk by } \\
\text { PM }_{3.5} \text { and components }\end{array}$ \\
\hline 21 & Lim, et al. $(2014)^{68}$ & GWR & 2008-2010 & Seoul & Cardiovascular & $\mathrm{PM}_{10}$ & & Mean $\beta$ (SE) 0.956 (0.102) \\
\hline & & & & & Unintentional injury & $\mathrm{PM}_{10}$ & IQR $\left(48.3 \mu \mathrm{g} / \mathrm{m}^{3}\right)$ & NS \\
\hline & & & & & Unintentional injury & $\mathrm{SO}_{2}$ & IOR (0.005 ppm) & OR $1.119(1.022,1.226)$ \\
\hline 22 & Ha, et al. $(2015)^{69}$ & Case-crossover & 2002-2008 & 7 cities & Unintentional injury & $\mathrm{NO}_{2}$ & IOR (0.02 ppm) & OR $1.208(1.043,1.400)$ \\
\hline & & & & & Unintentional injury & $\mathrm{O}_{3}$ & IQR (0.03 ppm) & NS \\
\hline & & & & & Unintentional injury & $\mathrm{CO}$ & IOR (0.36 ppm) & OR $1.012(1.000,1.024)$ \\
\hline 23 & Kim, et al. $(2017)^{16}$ & Time-series & 1993-2009 & 7 cities & Non-accidental & $\mathrm{PM}_{10}$ & $10 \mu \mathrm{g} / \mathrm{m}^{3}$ & $0.51 \%(0.01,1.01)$ \\
\hline & & & & & Non-accidental & $\mathrm{PM}_{10}$ & $\begin{array}{l}\text { Daily } \\
\text { concentrations } \\
\text { of } \geq 75 \mu \mathrm{g} / \mathrm{m}^{3}\end{array}$ & $0.48 \%(0.30,0.60)$ \\
\hline 24 & Kim, et al. $(2018)^{70}$ & Time-series & 1993-2009 & 7 cities & Cardiovascular & $\mathrm{PM}_{10}$ & $\begin{array}{l}\text { Daily } \\
\text { concentrations } \\
\text { of } \geq 75 \mu \mathrm{g} / \mathrm{m}^{3}\end{array}$ & $0.48 \%(0.14,0.82)$ \\
\hline & & & & & Respiratory & $\mathrm{PM}_{10}$ & $\begin{array}{l}\text { Daily } \\
\text { concentrations } \\
\text { of } \geq 75 \mu \mathrm{g} / \mathrm{m}^{3}\end{array}$ & $1.13 \%(0.37,1.89)$ \\
\hline
\end{tabular}


Sanghyuk Bae and Ho-jang Kwon

Table 1. Epidemiological Studies on Air Pollution and Mortality in Korea between 1999 and 2018 (Continued)

\begin{tabular}{|c|c|c|c|c|c|c|c|c|}
\hline No. & Author (year) & Study design & Study period & Location & Outcome & Pollutant & Unit & Effect size \\
\hline \multirow{15}{*}{25} & \multirow{15}{*}{ Kim, et al. $(2017)^{18}$} & \multirow{15}{*}{ Cohort } & \multirow{15}{*}{$2007-2013$} & \multirow{15}{*}{ Seoul } & $\begin{array}{l}\text { Composite } \\
\text { cardiovascular } \\
\text { events }\end{array}$ & $\mathrm{PM}_{2.5}$ & $1 \mu \mathrm{g} / \mathrm{m}^{3}$ & HR $1.41(1.32,1.50)$ \\
\hline & & & & & All-cause & $\mathrm{PM}_{2.5}$ & $1 \mu \mathrm{g} / \mathrm{m}^{3}$ & HR $1.32(1.22,1.43)$ \\
\hline & & & & & Cardiovascular & $\mathrm{PM}_{2.5}$ & $1 \mu \mathrm{g} / \mathrm{m}^{3}$ & HR $1.36(1.11,1.66)$ \\
\hline & & & & & $\begin{array}{l}\text { Composite } \\
\text { cardiovascular } \\
\text { events }\end{array}$ & $\mathrm{CO}$ & IQR (0.25 ppm) & HR $1.79(1.61,1.99)$ \\
\hline & & & & & All-cause & $\mathrm{CO}$ & IOR (0.25 ppm) & HR $1.72(1.52,1.94)$ \\
\hline & & & & & Cardiovascular & $\mathrm{CO}$ & IOR (0.25 ppm) & HR $2.96(2.12,4.14)$ \\
\hline & & & & & $\begin{array}{l}\text { Composite } \\
\text { cardiovascular } \\
\text { events }\end{array}$ & $\mathrm{SO}_{2}$ & IOR (2.54 ppb) & HR $1.94(1.78,2.11)$ \\
\hline & & & & & All-cause & $\mathrm{SO}_{2}$ & IOR (2.54 ppb) & HR $1.73(1.55,1.92)$ \\
\hline & & & & & Cardiovascular & $\mathrm{SO}_{2}$ & IOR (2.54 ppb) & HR $1.50(1.14,1.96)$ \\
\hline & & & & & $\begin{array}{l}\text { Composite } \\
\text { cardiovascular } \\
\text { events }\end{array}$ & $\mathrm{NO}_{2}$ & IQR (18.4 ppb) & HR $2.30(2.08,2.55)$ \\
\hline & & & & & All-cause & $\mathrm{NO}_{2}$ & IOR (18.4 ppb) & HR $1.79(1.59,2.03)$ \\
\hline & & & & & Cardiovascular & $\mathrm{NO}_{2}$ & IQR (18.4 ppb) & HR $2.67(1.94,3.69)$ \\
\hline & & & & & $\begin{array}{c}\text { Composite cardio- } \\
\text { vascular events }\end{array}$ & $\mathrm{O}_{3}$ & IOR (15.9 ppb) & HR $0.63(0.63,0.73)$ \\
\hline & & & & & All-cause & $\mathrm{O}_{3}$ & IQR (15.9 ppb) & HR $0.68(0.63,0.73)$ \\
\hline & & & & & Cardiovascular & $\mathrm{O}_{3}$ & IOR (15.9 ppb) & HR $0.59(0.49,0.71)$ \\
\hline \multirow{6}{*}{26} & \multirow{6}{*}{ Kim, et al. $(2017)^{17}$} & \multirow{6}{*}{ Cohort } & \multirow{6}{*}{ 2002-2014 } & \multirow{6}{*}{ Korea } & Non-accidental & $\mathrm{PM}_{10}$ & $10 \mu \mathrm{g} / \mathrm{m}^{3}$ & HR $1.05(0.99,1.11)$ \\
\hline & & & & & Cardiovascular & $\mathrm{PM}_{10}$ & $10 \mu \mathrm{g} / \mathrm{m}^{3}$ & HR $1.02(0.90,1.16)$ \\
\hline & & & & & Cerebrovascular & $\mathrm{PM}_{10}$ & $10 \mu \mathrm{g} / \mathrm{m}^{3}$ & HR $1.14(0.93,1.39)$ \\
\hline & & & & & Respiratory & $\mathrm{PM}_{10}$ & $10 \mu \mathrm{g} / \mathrm{m}^{3}$ & HR $1.19(0.91,1.57)$ \\
\hline & & & & & Cancer & $\mathrm{PM}_{10}$ & $10 \mu \mathrm{g} / \mathrm{m}^{3}$ & HR $1.02(0.95,1.10)$ \\
\hline & & & & & Lung cancer & $\mathrm{PM}_{10}$ & $10 \mu \mathrm{g} / \mathrm{m}^{3}$ & HR $0.96(0.82,1.13)$ \\
\hline \multirow{5}{*}{27} & \multirow{5}{*}{ Lee, et al. $(2018)^{71}$} & \multirow{5}{*}{ Case-crossover } & \multirow{5}{*}{ 2002-2013 } & \multirow{5}{*}{26 cities } & \multirow{5}{*}{ Suicide } & $\mathrm{PM}_{10}$ & IQR & Increased OR 1.2\% $(0.2,2.3)$ \\
\hline & & & & & & $\mathrm{NO}_{2}$ & IQR & Increased OR 4.3\% $(1.9,6.7)$ \\
\hline & & & & & & $\mathrm{SO}_{2}$ & IQR & Increased OR 2.2\% $(0.7,3.8)$ \\
\hline & & & & & & $\mathrm{CO}$ & IQR & Increased OR 2.4\% $(0.9,3.8)$ \\
\hline & & & & & & $\mathrm{O}_{3}$ & IQR & Increased OR $1.5 \%(-0.3,3.2)$ \\
\hline
\end{tabular}

TSP, total suspended particles; IQR, interquartile range; OR, odds ratio; RR, relative risk; HR, hazard ratio; NS, not significant; GWR, geographically weighted regression; 7 cities, Seoul, Incheon, Daejeon, Gwangju, Daegu, Busan, Ulsan.

\section{Air pollution and mortality}

Among the included studies, the earliest reports regarding an association between air pollution and mortality in Korea were published in 1999. ${ }^{10-13}$ Three of these were time series studies and one was a case-crossover study. Both time series and casecrossover designs are suitable for analysis of acute effects (in days) of short-term exposure to air pollution. One time series analysis was conducted in Seoul and Ulsan. That study reported that the daily variation of ambient concentrations of sulfur dioxide $\left(\mathrm{SO}_{2}\right)$, total suspended particles (TSP), and $\mathrm{O}_{3}$ in Seoul were significantly associated with increased non-accidental mortality. ${ }^{10}$ In the same year, the results of reanalysis of Seoul data from the previous time series using a case-crossover ap- proach, in which each participant became its own control, were reported, showing that only $\mathrm{SO}_{2}$ was significantly associated with non-accidental mortality. ${ }^{12}$ Another time series study conducted in Incheon showed that, in addition to TSP, a 10- $\mu \mathrm{g} /$ $\mathrm{m}^{3}$ increase in the daily mean concentration of $\mathrm{PM}_{10}$ was also associated with a $1.2 \%$ increase in total mortality. ${ }^{13}$ The remaining study was the first to examine the effects of all five criteria pollutants $\left[\mathrm{PM}_{10}, \mathrm{SO}_{2}, \mathrm{NO}_{2}\right.$, carbon monoxide (CO), and $\mathrm{O}_{3}$ ] on mortality in Seoul. That study reported that the previous day's concentrations of $\mathrm{PM}_{10}$ and $\mathrm{NO}_{2}$ were significantly associated with increased daily mortality [relative risks (RRs) of 1.0007 and 1.0026 for $\mathrm{PM}_{10}$ and $\mathrm{NO}_{2}$, respectively]. ${ }^{11}$

After 1999, most subsequent studies examined the associa- 
tions between air pollutants and total or non-accidental mortality using time series analysis and a case-crossover design. However, the effect sizes varied according to different studies. For instance, the percent increase in mortality for an interquartile range (IQR) increment in $\mathrm{PM}_{10}$ ranged between $0.9 \%{ }^{14}$ and $3.7 \%{ }^{15}$ This may be due to different factors of these studies, including the study period and area, and a multi-city study may provide more robust effect size. There were few multi-city studies and even fewer reported associations with total mortality. The most recent such study stated that a $10-\mu \mathrm{g} / \mathrm{m}^{3}$ increase in daily ambient $\mathrm{PM}_{10}$ was associated with a $0.51 \%$ increase in mortality. ${ }^{16}$

The effects of air pollution are not only acute but also chronic, and long-term exposure is generally expected to have a much higher effect size than short-term exposure. However, the chronic effect of air pollution has rarely been examined in Korea. In fact, there were only two studies reporting long-term effects of PM exposure on mortality among our search results, one each for $\mathrm{PM}_{10}$ and $\mathrm{PM}_{2.5}$. Kim, et al. ${ }^{17}$ analyzed a sample cohort of the National Health Insurance Service and reported a marginally significant $5 \%$ increase in mortality per a $10-\mu \mathrm{g} /$ $\mathrm{m}^{3}$ increase in annual $\mathrm{PM}_{10}$ concentration. Another study reported a hazard ratio (HR) of 1.32 for all-cause mortality with an increment of $1 \mu \mathrm{g} / \mathrm{m}^{3}$ in $\mathrm{PM}_{2.5}{ }^{18}$ Long-term exposure to other gaseous pollutants was also found to be associated with increased risk of mortality, and $\mathrm{CO}, \mathrm{SO}_{2}$, and $\mathrm{NO}_{2}$ showed $\mathrm{HRs}$ of $1.72,1.73$, and 1.79 for each IQR increase, respectively.

The effect of air pollution exposure on mortality is causespecific, and the related cardiovascular and respiratory effects are well known. There have been several reports on cardiovascular and respiratory mortality owing to air pollution in Korea. An interesting cause of death that shows an association with air pollution is suicide. In a case-crossover study conducted using data from seven metropolitan cities in Korea (Seoul, Incheon, Daejeon, Gwangju, Daegu, Busan, and Ulsan), the authors reported that an IQR increase of $\mathrm{PM}_{2.5}$ was associated with a $10.1 \%$ increase in the number of suicides. ${ }^{19}$

Most gaseous air pollutants $\left(\mathrm{SO}_{2}, \mathrm{NO}_{2}\right.$, and $\left.\mathrm{CO}\right)$ showed consistently significant associations with increased mortality. For acute exposure, an IQR increase of $\mathrm{SO}_{2}, \mathrm{NO}_{2}$, and $\mathrm{CO}$ increased daily mortality about $2 \%$, and an IQR increase in chronic exposure to those three pollutants showed consistent RRs of around 1.7 (Table 1). However, the association between ambient $\mathrm{O}_{3}$ concentration and mortality seems inconclusive. Two studies reported significant positive associations of $\mathrm{O}_{3}$ concentration with total mortality ${ }^{20}$ and ischemic stroke mortality. ${ }^{21}$ However, we also found reports of significant negative associations with all-cause, ${ }^{13,18}$ cardiovascular, ${ }^{18}$ and infant mortality. ${ }^{22}$

\section{Air pollution and morbidity}

Asthma and respiratory diseases were among the first specific disorders analyzed in Korea. A time series analysis conducted in Seoul reported that an IQR increase in $\mathrm{PM}_{10}, \mathrm{SO}_{2}, \mathrm{NO}_{2}, \mathrm{CO}$, and $\mathrm{O}_{3}$ showed significant RRs for children's asthma hospitalization of 1.07, 1.11, 1.15, 1.16 and 1.12, respectively. ${ }^{23}$ Another study reported the results of a children's panel for $\mathrm{NO}_{2}$ exposure showing an OR of 1.12 for upper respiratory symptoms and ORs for lower respiratory symptoms of 1.18, 1.12, and 1.16 for increased exposures to $\mathrm{NO}_{2}, \mathrm{SO}_{2}$, and CO, respectively. ${ }^{24} \mathrm{O}_{3}$ was also associated with children's asthma hospitalization, especially in groups with lower socioeconomic status (RR: 1.32, 95\% CI: $1.11,1.58) .{ }^{25}$ In a cohort study, $\mathrm{O}_{3}$ concentration was associated with a 12-month prevalence of wheeze $\mathrm{e}^{26}$ and airway hyperresponsiveness ${ }^{27}$ in children. Other allergic disorders, such as allergic rhinitis and atopic dermatitis, were also associated with air pollution (Table 2).

Similar to the association between air pollution and cardiovascular mortality, the morbidity of cardiovascular and cerebrovascular diseases, such as stroke, myocardial infarction, and hypertension, were also significantly associated with increased exposure to air pollution. A time series analysis reported that $\mathrm{NO}_{2}$ increased stroke $(\mathrm{RR}=1.2, p$-value $=0.001),{ }^{28}$ and a cohort study reported that long-term exposure to $\mathrm{PM}_{2.5}, \mathrm{CO}$, $\mathrm{SO}_{2}$, and $\mathrm{NO}_{2}$ increased the risk of acute myocardial infarction, congestive heart failure, and stroke (Table 2). ${ }^{18}$

We found two studies examining the association of air pollution with cancer. In these recent studies, indoor radon concentrations were associated with an increased risk of male lung cancer and non-Hodgkin's lymphoma in girls, ${ }^{29}$ and conventional air pollutants $\left(\mathrm{PM}_{10}\right.$ and $\left.\mathrm{NO}_{2}\right)$ were associated with lung cancer with marginal significance. ${ }^{30}$

Similar to the association of suicide with air pollution, depressive symptoms were also found to be associated with air pollution in Korea. A panel study examining air pollution and depressive symptoms was one of the first to report such an association. ${ }^{31}$ An association between $\mathrm{PM}_{2.5}$ and major depressive disorder was also found in a community-based urban cohort. $^{32}$

Birth outcome has been another subject of analysis. $\mathrm{PM}_{10}$, $\mathrm{SO}_{2}$, and $\mathrm{CO}$ exposures were reported to have significant associations with low birth weight in a cohort study. ${ }^{33,34}$

\section{Health impact assessment}

Among four studies (Table 3), two calculated the attributable number of deaths, ${ }^{35,36}$ one calculated the attributable number of deaths and morbidity, ${ }^{37}$ and a fourth calculated DALYs. ${ }^{38}$

There were substantial differences in the attributable number of deaths among the study results. For instance, Leem, et al. ${ }^{37}$ estimated the number of deaths attributable to $\mathrm{PM}_{2.5}$ to be 15346 in the Seoul metropolitan area, whereas Han, et al. ${ }^{36}$ estimated this number to be 1763 . Yorifuji, et al. ${ }^{35}$ estimated the number of deaths attributable to $\mathrm{PM}_{10}$ over $20 \mu \mathrm{g} / \mathrm{m}^{3}$ at 5840 in Seoul. These numbers are substantially different, even when considering the differences in study area, study period, and pollutants investigated. 
Sanghyuk Bae and Ho-jang Kwon

Table 2. Epidemiological Studies on Air Pollution and Morbidity in Korea between 1999 and 2018

\begin{tabular}{|c|c|c|c|c|c|c|c|c|}
\hline No. & Author (year) & Study design & $\begin{array}{l}\text { Study } \\
\text { period }\end{array}$ & Location & Outcome & Pollutant & Unit & Effect size \\
\hline \multirow{5}{*}{1} & \multirow{5}{*}{ Lee, et al. $(2002)^{23}$} & \multirow{5}{*}{ Time series } & & \multirow{5}{*}{ Seoul } & Asthma hospitalization & $\mathrm{PM}_{10}$ & $\operatorname{IQR}\left(40.4 \mu \mathrm{g} / \mathrm{m}^{3}\right)$ & $\operatorname{RR} 1.07(1.04,1.11)$ \\
\hline & & & & & Asthma hospitalization & $\mathrm{SO}_{2}$ & IOR (4.4 ppb) & RR $1.11(1.06,1.17)$ \\
\hline & & & & & Asthma hospitalization & $\mathrm{NO}_{2}$ & IOR (14.6 ppb) & RR 1.15 (1.10, 1.20) \\
\hline & & & & & Asthma hospitalization & $\mathrm{O}_{3}$ & IOR (21.7 ppb) & RR $1.12(1.07,1.16)$ \\
\hline & & & & & Asthma hospitalization & $\mathrm{CO}$ & IQR (1.0 ppm) & $\operatorname{RR} 1.16(1.10,1.22)$ \\
\hline & \multirow{4}{*}{ Lee, et al. $(2005)^{24}$} & \multirow{4}{*}{ Panel study } & \multirow{4}{*}{2003} & \multirow{4}{*}{ Seoul } & Upper respiratory symptoms & $\mathrm{NO}_{2}$ & & OR $1.12(1.01,1.24)$ \\
\hline & & & & & Lower respiratory symptoms & $\mathrm{NO}_{2}$ & & OR $1.18(1.06,1.31)$ \\
\hline & & & & & Lower respiratory symptoms & $\mathrm{SO}_{2}$ & & OR $1.12(1.01,1.25)$ \\
\hline & & & & & Lower respiratory symptoms & $\mathrm{CO}$ & & OR $1.16(1.02,1.32)$ \\
\hline \multirow{3}{*}{3} & \multirow{3}{*}{ Son, et al. $(2006)^{25}$} & \multirow{3}{*}{ Time series } & \multirow{3}{*}{2002} & \multirow{3}{*}{ Seoul } & $\begin{array}{l}\text { Asthma hospitalization } \\
\text { (highest SES) }\end{array}$ & $\mathrm{O}_{3}$ & & RR $1.12(1.00,1.25)$ \\
\hline & & & & & $\begin{array}{l}\text { Asthma hospitalization } \\
\text { (moderate SES) }\end{array}$ & $\mathrm{O}_{3}$ & & $\operatorname{RR} 1.24(1.08,1.43)$ \\
\hline & & & & & $\begin{array}{l}\text { Asthma hospitalization } \\
\text { (lowest SES) }\end{array}$ & $\mathrm{O}_{3}$ & & RR $1.32(1.11,1.58)$ \\
\hline 4 & Lee, et al. $(2007)^{72}$ & $\begin{array}{l}\text { Natural } \\
\text { experiment }\end{array}$ & 2002 & Busan & $\begin{array}{l}\text { Childhood asthma } \\
\text { hospitalization }\end{array}$ & & $\begin{array}{l}\text { RR post Asian } \\
\text { game period/ } \\
\text { RR baseline }\end{array}$ & $0.73(0.49,1.11)$ \\
\hline \multirow{3}{*}{5} & \multirow{3}{*}{ Lee, et al. $(2006)^{73}$} & \multirow{3}{*}{ Time series } & \multirow{3}{*}{2002} & \multirow{3}{*}{ Seoul } & Asthma hospitalization & $\mathrm{PM}_{10}$ & IOR & $31 \%(14,51)$ \\
\hline & & & & & Asthma hospitalization & $\mathrm{SO}_{2}$ & IQR & $29 \%(8,53)$ \\
\hline & & & & & Asthma hospitalization & $\mathrm{NO}_{2}$ & IQR & $29 \%(5,58)$ \\
\hline \multirow{4}{*}{6} & \multirow{4}{*}{ Seo, et al. $(2007)^{33}$} & \multirow{4}{*}{ Cohort } & \multirow{4}{*}{ 2002-2003 } & \multirow{4}{*}{ Seoul } & Low birth weight & $\mathrm{CO}$ & IQR & RR $1.081(1.002,1.166$ \\
\hline & & & & & Low birth weight & $\mathrm{SO}_{2}$ & IQR & RR $1.145(1.036,1.267$ \\
\hline & & & & & Low birth weight & $\mathrm{PM}_{10}$ & $\mathrm{IQR}$ & RR $1.053(1.002,1.108$ \\
\hline & & & & & Low birth weight & $\mathrm{NO}_{2}$ & IQR & RR $1.003(0.954,1.055$ \\
\hline 7 & Moon, et al. $(2009)^{74}$ & & & 4 cities & Respiratory symptoms & $\begin{array}{l}5 \text { criteria } \\
\text { pollutants }\end{array}$ & & $\begin{array}{l}\text { Significant positive } \\
\text { association with } \mathrm{SO}_{2} \\
\text { and } \mathrm{NO}_{2}\end{array}$ \\
\hline \multirow{7}{*}{8} & & & & Seoul & Low birth weight & $\mathrm{PM}_{10}$ & & OR $1.08(0.99,1.18)$ \\
\hline & & & & Busan & Low birth weight & $\mathrm{PM}_{10}$ & & OR $1.24(1.02,1.52)$ \\
\hline & & & & Daegu & Low birth weight & $\mathrm{PM}_{10}$ & & OR $1.19(1.04,1.37)$ \\
\hline & Seo, et al. $(2010)^{34}$ & Cohort & 2004 & Incheon & Low birth weight & $\mathrm{PM}_{10}$ & & OR $1.12(0.98,1.28)$ \\
\hline & & & & Gwangju & Low birth weight & $\mathrm{PM}_{10}$ & & OR $1.22(0.98,1.52)$ \\
\hline & & & & Daejeon & Low birth weight & $\mathrm{PM}_{10}$ & & OR $1.06(1.00,1.11)$ \\
\hline & & & & Ulsan & Low birth weight & $\mathrm{PM}_{10}$ & & OR $1.19(1.03,1.38)$ \\
\hline 9 & $\mathrm{Yj}_{\mathrm{i}}$ et al $(2010)^{75 *}$ & Case-crossover & 2001-2006 & & Cardiovascular hospitalization & $\mathrm{PM}_{10}$ & $10 \mu \mathrm{g} / \mathrm{m}^{3}$ & $0.77 \%(0.53,1.01)$ \\
\hline$y$ & Y, el al. (ZUIU) & lase-crossover & $\angle 001-\angle 000$ & & Respiratory hospitalization & $\mathrm{PM}_{10}$ & $10 \mu \mathrm{g} / \mathrm{m}^{3}$ & $1.19 \%(0.94,1.44)$ \\
\hline 10 & Kim, et al. $(2011)^{26}$ & Cohort & & & 12-month prevalence of wheeze & $\mathrm{O}_{3}$ & $5 \mathrm{ppb}$ & OR $1.372(1.016,1.852$ \\
\hline & & & & & Depression (SGDS-K) & $\mathrm{PM}_{10}$ & IQR & $17.0 \%(4.9,30.5)$ \\
\hline 11 & Lim, et al. $(2012)^{31}$ & Panel study & & Seoul & Depression (SGDS-K) & $\mathrm{NO}_{2}$ & $\mathrm{IQR}$ & $32.8 \%(12.6,65.6)$ \\
\hline & & & & & Depression (SGDS-K) & $\mathrm{O}_{3}$ & IQR & $43.7 \%(11.5,85.2)$ \\
\hline 12 & Kim, et al. $(2012)^{76}$ & Panel study & & Seoul & Insulin resistance & $\begin{array}{l}\mathrm{PM}_{10}, \mathrm{O}_{3} \\
\mathrm{NO}_{2}\end{array}$ & IQR & $\begin{array}{l}\text { Significantly } \\
\text { increased }\end{array}$ \\
\hline 13 & Kim, et al. $(2013)^{77}$ & Cross sectional & & & Allergic diseases & $\begin{array}{l}\text { Traffic } \\
\text { related } \\
\text { pollutants }\end{array}$ & $\begin{array}{l}\text { Polluted vs. } \\
\text { non-polluted } \\
\text { school }\end{array}$ & OR $2.12(1.41,3.19)$ \\
\hline 14 & & & & & Airway hyperresponsiveness & $\mathrm{O}_{3}$ & & OR $1.60(1.13,2.27)$ \\
\hline & & & & & New episodes of wheezing & $\mathrm{O}_{3}$ & & OR $1.92(0.96,3.83)$ \\
\hline
\end{tabular}


Table 2. Epidemiological Studies on Air Pollution and Morbidity in Korea between 1999 and 2018 (Continued)

\begin{tabular}{|c|c|c|c|c|c|c|c|c|}
\hline No. & Author (year) & Study design & $\begin{array}{l}\text { Study } \\
\text { period }\end{array}$ & Location & Outcome & Pollutant & Unit & Effect size \\
\hline 15 & Han, et al. $(2013)^{78}$ & & & & $\begin{array}{l}\text { Hemorrhagic fever with renal } \\
\text { syndrome }\end{array}$ & $\mathrm{PM}_{10}$ & $1 \mu \mathrm{g} / \mathrm{m}^{3}$ & $\begin{array}{c}0.013 \text { increase of } \\
\text { monthly cases }\end{array}$ \\
\hline \multirow{8}{*}{16} & \multirow{8}{*}{ Son, et al. $(2013)^{79}$} & & \multirow{8}{*}{ 2003-2008 } & \multirow{8}{*}{8 cities } & $\begin{array}{l}\text { Allergic disease hospital } \\
\text { admission }\end{array}$ & $\mathrm{PM}_{10}$ & $\operatorname{IQR}\left(30.7 \mu \mathrm{g} / \mathrm{m}^{3}\right)$ & $2.2 \%(0.5,3.9)$ \\
\hline & & & & & Asthma hospital admission & $\mathrm{PM}_{10}$ & $\operatorname{IQR}\left(30.7 \mu \mathrm{g} / \mathrm{m}^{3}\right)$ & $2.8 \%(1.3,4.4)$ \\
\hline & & & & & Respiratory hospital admission & $\mathrm{PM}_{10}$ & $\operatorname{IQR}\left(30.7 \mu \mathrm{g} / \mathrm{m}^{3}\right)$ & $1.7 \%(0.9,2.6)$ \\
\hline & & & & & $\begin{array}{l}\text { Cardiovascular hospital } \\
\text { admission }\end{array}$ & $\mathrm{PM}_{10}$ & $\operatorname{IQR}\left(30.7 \mu \mathrm{g} / \mathrm{m}^{3}\right)$ & $0.7 \%(0.0,1.4)$ \\
\hline & & & & & $\begin{array}{l}\text { Allergic disease hospital } \\
\text { admission }\end{array}$ & $\mathrm{NO}_{2}$ & IOR (12.2 ppb) & $2.3 \%(0.6,4.0)$ \\
\hline & & & & & Asthma hospital admission & $\mathrm{NO}_{2}$ & IOR (12.2 ppb) & $2.2 \%(0.3,4.1)$ \\
\hline & & & & & Respiratory hospital admission & $\mathrm{NO}_{2}$ & IOR (12.2 ppb) & $2.2 \%(0.6,3.7)$ \\
\hline & & & & & $\begin{array}{l}\text { Cardiovascular hospital } \\
\text { admission }\end{array}$ & $\mathrm{NO}_{2}$ & IQR (12.2 ppb) & $2.2 \%(1.1,3.4)$ \\
\hline 17 & Park, et al. $(2013)^{80}$ & Time series & & 7 cities & Asthma admission & $\begin{array}{r}\mathrm{PM}_{10}, \mathrm{CO} \\
\mathrm{O}_{3}, \mathrm{NO}_{2}\end{array}$ & $\begin{array}{l}\text { Children vs. } \\
\text { adult }\end{array}$ & $\begin{array}{l}\text { Lower risk in children } \\
\text { for } \mathrm{PM}_{10} \text { and } \mathrm{CO}\end{array}$ \\
\hline \multirow{2}{*}{18} & \multirow{2}{*}{ Kim, et al. $(2014)^{81}$} & \multirow{2}{*}{ Cohort } & & & Neurodevelopment (MDI) & $\mathrm{PM}_{10}$ & & $\beta=-2.83 ; p=0.003$ \\
\hline & & & & & Neurodevelopment (PDI) & $\mathrm{PM}_{10}$ & & $\beta=-3.00 ; p=0.002$ \\
\hline 19 & Hwang, et al. (2014) & $\begin{array}{l}\text { Retrospective } \\
\text { cohort }\end{array}$ & & Seoul & Tuberculosis & $\mathrm{SO}_{2}$ & IOR & RR $1.07(1.03,1.12)$ \\
\hline 20 & Han, et al. $(2015)^{28}$ & Time series & 2004-2013 & & Stroke & $\mathrm{NO}_{2}$ & & RR $1.262, p=0.001$ \\
\hline \multirow{2}{*}{21} & \multirow{2}{*}{ Kim, et al. $(2015)^{83}$} & \multirow{2}{*}{ Case-crossover } & & \multirow{2}{*}{ Korea } & Hourly asthma ED visit & $\mathrm{PM}_{10-2.5}$ & IQR & OR $1.05(1.00,1.11)$ \\
\hline & & & & & Hourly asthma ED visit & $\mathrm{O}_{3}$ & IQR & OR $1.10(1.04,1.16)$ \\
\hline 22 & Jang, et al. $(2015)^{84}$ & Ecological & & Korea & Monthly malaria incidence & $\mathrm{NO}_{2}$ & & $\beta=-0.884, p<0.01$ \\
\hline \multirow{2}{*}{23} & \multirow{2}{*}{ Shim, et al. $(2016)^{85}$} & \multirow{2}{*}{ Cross sectional } & \multirow{2}{*}{ 2010-2013 } & \multirow{2}{*}{ Korea } & Benign prostate hyperplasia & $\mathrm{NO}_{2}$ & & OR $2.23(1.55,2.39)$ \\
\hline & & & & & Benign prostate hyperplasia & $\mathrm{SO}_{2}$ & & OR $2.02(1.42,2.88)$ \\
\hline 24 & Kang, et al. $(2016)^{86}$ & Time series & 2006-2013 & Seoul & Cardiac arrest & $\mathrm{PM}_{2.5}$ & $10 \mu \mathrm{g} / \mathrm{m}^{3}$ & $1.30 \%(0.20,2.41)$ \\
\hline \multirow[t]{2}{*}{25} & \multirow[t]{2}{*}{ Kim, et al. $(2016)^{87}$} & \multirow[t]{2}{*}{ Cross sectional } & & & Allergic rhinitis & $\begin{array}{l}\text { CO (during } \\
\text { the first } \\
\text { year of life) }\end{array}$ & $100 \mathrm{ppb}$ & OR $1.10(1.03,1.19)$ \\
\hline & & & & & Atopic dermatitis & $\begin{array}{l}\text { CO (past } 12 \\
\text { months) }\end{array}$ & 1 ppm & OR $8.11(1.06,62.12)$ \\
\hline \multirow{4}{*}{26} & \multirow{4}{*}{ Kim, et al. $(2016)^{88}$} & \multirow{4}{*}{ Cross sectional } & & & Asthma & $\mathrm{NO}_{2}$ & & OR $1.67(1.03,2.71)$ \\
\hline & & & & & Allergic rhinitis & Black carbon & & OR $1.60(1.36,1.90)$ \\
\hline & & & & & Allergic rhinitis & $\mathrm{SO}_{2}$ & & OR $1.09(1.01,1.17)$ \\
\hline & & & & & Allergic rhinitis & $\mathrm{NO}_{2}$ & & OR $1.18(1.07,1.30)$ \\
\hline \multirow{2}{*}{27} & \multirow{2}{*}{ Han, et al. $(2016)^{89}$} & & & Seongdong-gu, & Intracerebral hemorrhage & $\mathrm{PM}_{10}$ & & RR $1.09(1.02,1.15)$ \\
\hline & & lime serıes & $2004-2014$ & Seoul & Subarachnoid hemorrhage & $\mathrm{O}_{3}$ & & $\operatorname{RR} 1.32(1.10,1.58)$ \\
\hline 28 & Kim, et al. $(2016)^{32}$ & Cohort & $2002-2010$ & Korea & Major depressive disorder & $\mathrm{PM}_{2.5}$ & $10 \mu \mathrm{g} / \mathrm{m}^{3}$ & HR 1.44 (1.17-1.78) \\
\hline & & & & & Hypertension & $\mathrm{PM}_{10}$ & $10 \mu \mathrm{g} / \mathrm{m}^{3}$ & OR $1.042(1.009,1.077)$ \\
\hline & & & & & Hypertension in $>30$ years old & $\mathrm{PM}_{10}$ & $10 \mu \mathrm{g} / \mathrm{m}^{3}$ & OR 1.044 (1.009, 1.079) \\
\hline & & & & & Stroke & $\mathrm{PM}_{10}$ & $10 \mu \mathrm{g} / \mathrm{m}^{3}$ & OR $1.044(0.979,1.114)$ \\
\hline & & & & & Angina & $\mathrm{PM}_{10}$ & $10 \mu \mathrm{g} / \mathrm{m}^{3}$ & OR 0.977 (0.901, 1.059) \\
\hline & & & & & Hypertension & $\mathrm{NO}_{2}$ & $10 \mathrm{ppb}$ & OR $1.077(1.044,1.112)$ \\
\hline 29 & Lee, et al. $(2016)^{90}$ & Cross sectional & $2008-2010$ & Korea & Hypertension in $>30$ years old & $\mathrm{NO}_{2}$ & $10 \mathrm{ppb}$ & OR $1.080(1.043,1.118)$ \\
\hline & & & & & Stroke & $\mathrm{NO}_{2}$ & $10 \mathrm{ppb}$ & OR $1.073(0.994,1.157)$ \\
\hline & & & & & Angina & $\mathrm{NO}_{2}$ & $10 \mathrm{ppb}$ & OR $1.047(0.968,1.134)$ \\
\hline & & & & & Hypertension & $\mathrm{CO}$ & $10 \mathrm{ppb}$ & OR $1.123(0.963,1.310)$ \\
\hline & & & & & Hypertension in $>30$ years old & $\mathrm{CO}$ & $10 \mathrm{ppb}$ & OR $1.129(0.963,1.387)$ \\
\hline & & & & & Stroke & $\mathrm{CO}$ & $10 \mathrm{ppb}$ & OR $1.336(0.987,2.011)$ \\
\hline
\end{tabular}


Sanghyuk Bae and Ho-jang Kwon

Table 2. Epidemiological Studies on Air Pollution and Morbidity in Korea between 1999 and 2018 (Continued)

\begin{tabular}{|c|c|c|c|c|c|c|c|c|}
\hline No. & Author (year) & Study design & $\begin{array}{l}\text { Study } \\
\text { period }\end{array}$ & Location & Outcome & Pollutant & Unit & Effect size \\
\hline 30 & Lee, et al. $(2017)^{91}$ & Cross sectional & $2008-2011$ & Korea & Pterygium & $\mathrm{PM}_{10}$ & $5 \mu \mathrm{g} / \mathrm{m}^{3}$ & OR $1.23 p=0.023$ \\
\hline \multirow{2}{*}{31} & \multirow{2}{*}{ Chung, et al. $(2017)^{92}$} & & & & Cardioembolic stroke & $\mathrm{PM}_{10}$ & & Significantly increased \\
\hline & & & & & Cardioembolic stroke & $\mathrm{SO}_{2}$ & & Significantly increased \\
\hline 32 & Kim, et al. $(2016)^{93}$ & $\begin{array}{l}\text { Randomized } \\
\text { intervention } \\
\text { trial }\end{array}$ & & & Atopic dermatitis & $\begin{array}{l}\text { Indoor } \\
\text { VOC }\end{array}$ & $\begin{array}{l}\text { Environmentally } \\
\text { friendly vs. } \\
\text { PVC wallpaper }\end{array}$ & $\begin{array}{l}\text { More improvement in } \\
\text { environmentally } \\
\text { friendly wallpaper } \\
\text { group }\end{array}$ \\
\hline \multirow[b]{2}{*}{33} & \multirow[b]{2}{*}{ Ha, et al. $(2017)^{29}$} & & \multirow[b]{2}{*}{ 1999-2008 } & & Male lung cancer & Indoor radon & $10 \mathrm{~Bq} / \mathrm{m}^{3}$ & $1 \%$ \\
\hline & & Ecological & & & $\begin{array}{l}\text { Female children non-Hodgkin's } \\
\text { Iymphoma }\end{array}$ & Indoor radon & $10 \mathrm{~Bq} / \mathrm{m}^{3}$ & $7 \%$ \\
\hline 34 & Hwang, et al. $(2017)^{94}$ & Time series & & & Cardiovascular ED visit & $\begin{array}{l}\mathrm{NH} 4+ \\
\left(\mathrm{PM}_{2.5}\right. \\
\text { component) }\end{array}$ & & RR $1.05(1.01,1.09)$ \\
\hline \multirow{15}{*}{35} & \multirow{15}{*}{ Kim, et al. $(2017)^{18 *}$} & \multirow{15}{*}{ Cohort } & \multirow{15}{*}{ 2007-2013 } & \multirow{15}{*}{ Seoul } & Acute myocardial infarction & $\mathrm{PM}_{2.5}$ & $1 \mu \mathrm{g} / \mathrm{m}^{3}$ & $1.36(1.19,1.56)$ \\
\hline & & & & & Congestive heart failure & $\mathrm{PM}_{2.5}$ & $1 \mu \mathrm{g} / \mathrm{m}^{3}$ & $1.44(1.29,1.61)$ \\
\hline & & & & & Stroke & $\mathrm{PM}_{2.5}$ & $1 \mu \mathrm{g} / \mathrm{m}^{3}$ & $1.39(1.27,1.52)$ \\
\hline & & & & & Acute myocardial infarction & $\mathrm{CO}$ & IQR (0.25 ppm) & $2.12(1.72,2.61)$ \\
\hline & & & & & Congestive heart failure & $\mathrm{CO}$ & IOR (0.25 ppm) & $1.86(1.56,2.21)$ \\
\hline & & & & & Stroke & $\mathrm{CO}$ & IOR (0.25 ppm) & $2.00(1.73,2.30)$ \\
\hline & & & & & Acute myocardial infarction & $\mathrm{SO}_{2}$ & IOR (2.54 ppb) & $1.82(1.52,2.19)$ \\
\hline & & & & & Congestive heart failure & $\mathrm{SO}_{2}$ & IOR (2.54 ppb) & $2.00(1.73,2.32)$ \\
\hline & & & & & Stroke & $\mathrm{SO}_{2}$ & IOR (2.54 ppb) & $2.25(2.00,2.54)$ \\
\hline & & & & & Acute myocardial infarction & $\mathrm{NO}_{2}$ & IOR (18.4 ppb) & $1.81(1.46,2.25)$ \\
\hline & & & & & Congestive heart failure & $\mathrm{NO}_{2}$ & IQR (18.4 ppb) & $2.40(2.02,2.85)$ \\
\hline & & & & & Stroke & $\mathrm{NO}_{2}$ & IOR (18.4 ppb) & $2.65(2.29,3.06)$ \\
\hline & & & & & Acute myocardial infarction & $\mathrm{O}_{3}$ & IOR (15.9 ppb) & $0.71(0.63,0.82)$ \\
\hline & & & & & Congestive heart failure & $\mathrm{O}_{3}$ & IQR (15.9 ppb) & $0.64(0.58,0.71)$ \\
\hline & & & & & Stroke & $\mathrm{O}_{3}$ & IOR (15.9 ppb) & $0.60(0.55,0.65)$ \\
\hline \multirow{2}{*}{36} & \multirow{2}{*}{$\begin{array}{l}\text { Lamichhane, et al. } \\
(2017)^{30}\end{array}$} & \multirow{2}{*}{ Case-control } & & \multirow{2}{*}{ Korea } & \multirow{2}{*}{ Lung cancer } & $\mathrm{PM}_{10}$ & $10 \mu \mathrm{g} / \mathrm{m}^{3}$ & OR $1.09(0.96,1.23)$ \\
\hline & & & & & & $\mathrm{NO}_{2}$ & $10 \mathrm{ppb}$ & OR $1.10(1.00,1.22)$ \\
\hline \multirow[b]{2}{*}{37} & \multirow[b]{2}{*}{ Yi, et al. $(2017)^{95}$} & \multirow[b]{2}{*}{ Cross sectional } & & \multirow[b]{2}{*}{ Seoul } & \multirow[b]{2}{*}{ Children's atopic eczema } & Road density & & OR $1.08(1.01,1.15)$ \\
\hline & & & 2010 & & & $\begin{array}{l}\text { Road } \\
\text { proximity }\end{array}$ & & OR $1.15(1.01,1.31)$ \\
\hline \multirow{2}{*}{38} & \multirow{2}{*}{$\begin{array}{l}\text { Lamichhane, et al. } \\
(2018)^{96}\end{array}$} & \multirow{2}{*}{ Birth cohort } & & & Fetal arowth (BPD) & $\mathrm{PM}_{10}$ & $10 \mu \mathrm{g} / \mathrm{m}^{3}$ & $-0.26 \mathrm{~mm}(-0.41,-0.11)$ \\
\hline & & & & & & $\mathrm{NO}_{2}$ & $10 \mu \mathrm{g} / \mathrm{m}^{3}$ & $-0.30 \mathrm{~mm}(-0.59,-0.03)$ \\
\hline
\end{tabular}

SES, socioeconomic status; SGDS-K, Short Geriatric Depression Scale-Korean; MDI, mental developmental index; PDI, psychomotor developmental index; BPD, biparietal diameter; VOC, volatile organic carbon; PVC: polyvinyl chloride; IQR, interquartile range; OR, odds ratio; RR, relative risk; HR, hazard ratio; 7 cities, Seoul, Incheon, Daejeon, Gwangju, Daegu, Busan, Ulsan.

*From the search results of mortality studies.

\section{DISCUSSION}

Beginning in 1999, many studies have been conducted to elucidate the health effects of air pollution in Korea. These studies have reported associations with mortality (all-cause, respiratory, cerebrovascular, cardiovascular, infant, injury, and suicide) and morbidity (allergic, respiratory, cardiovascular, cerebrovascular, adverse birth outcomes, depression, and cancer). Most studies examined the short-term effects of air pollution using a time series or case-crossover study design; we found only three cohort studies that examined long-term effects. There were four studies that estimated the health impacts of air pollution, and except for one study that reported DALYs, three studies had inconsistent estimations of the attributable number of deaths.

Estimating health impacts is usually conducted later than other research as previously estimated associations between exposure and outcome, or concentration-response function (C-R function) are required. ${ }^{39}$ Naturally, the estimated health impact depends on the C-R function used. We suspect that differences in the attributable number of deaths estimated in the three studies reviewed here is partly due to the different 
Table 3. Studies Estimating Health Impact of Air Pollution Conducted in Korea

\begin{tabular}{|c|c|c|c|c|c|c|}
\hline No. & Autor (year) & $\begin{array}{l}\text { Study } \\
\text { period }\end{array}$ & Location & Outcome & Pollutant & $\begin{array}{l}\text { Health impact } \\
\text { (person) }\end{array}$ \\
\hline \multirow{8}{*}{1} & \multirow{8}{*}{ Leem, et al. $(2015)^{37}$} & \multirow{8}{*}{2010} & \multirow{8}{*}{$\begin{array}{c}\text { Seoul } \\
\text { metropolitan } \\
\text { area }\end{array}$} & Attributable number of deaths & $\mathrm{PM}_{2.5}$ & 15346 \\
\hline & & & & Attributable number of respiratory hospital admission & $\mathrm{PM}_{10}$ & 12511 \\
\hline & & & & Attributable number of cardiovascular hospital admission & $\mathrm{PM} 1_{0}$ & 12351 \\
\hline & & & & Attributable number of lung cancer incidence & $\mathrm{PM}_{10}$ & 1403 \\
\hline & & & & Attributable number of asthma attack (children) & $\mathrm{PM}_{10}$ & 11389 \\
\hline & & & & Attributable number of asthma attack (adults) & $\mathrm{PM}_{10}$ & 44006 \\
\hline & & & & Attributable number of chronic bronchitis & $\mathrm{PM}_{10}$ & 20490 \\
\hline & & & & Attributable number of acute bronchitis & $\mathrm{PM}_{10}$ & 278346 \\
\hline \multirow{7}{*}{2} & \multirow{7}{*}{ Yorifuji, et al. $(2015)^{35}$} & \multirow{7}{*}{2009} & Seoul & Attributable number of deaths & $\mathrm{PM}_{10}$ over $20 \mu \mathrm{g} / \mathrm{m}^{3}$ & 5840 \\
\hline & & & Busan & Attributable number of deaths & $\mathrm{PM}_{10}$ over $20 \mu \mathrm{g} / \mathrm{m}^{3}$ & 2465 \\
\hline & & & Daegu & Attributable number of deaths & $\mathrm{PM}_{10}$ over $20 \mu \mathrm{g} / \mathrm{m}^{3}$ & 1466 \\
\hline & & & Incheon & Attributable number of deaths & $\mathrm{PM}_{10}$ over $20 \mu \mathrm{g} / \mathrm{m}^{3}$ & 1931 \\
\hline & & & Daejeon & Attributable number of deaths & $\mathrm{PM}_{10}$ over $20 \mu \mathrm{g} / \mathrm{m}^{3}$ & 599 \\
\hline & & & Gwangju & Attributable number of deaths & $\mathrm{PM}_{10}$ over $20 \mu \mathrm{g} / \mathrm{m}^{3}$ & 698 \\
\hline & & & Ulsan & Attributable number of deaths & $\mathrm{PM}_{10}$ over $20 \mu \mathrm{g} / \mathrm{m}^{3}$ & 539 \\
\hline 3 & Yoon, et al. $(2015)^{38}$ & 2007 & Korea & Disability-adjusted life years & Out door air pollution & $6.89 / 1000$ person \\
\hline \multirow{9}{*}{4} & \multirow{9}{*}{ Han, et al. $(2018)^{36}$} & \multirow{9}{*}{2015} & Korea & Attributable number of deaths & $\mathrm{PM}_{2.5}$ & 11924 \\
\hline & & & Seoul & Attributable number of deaths & $\mathrm{PM}_{2.5}$ & 1763 \\
\hline & & & Busan & Attributable number of deaths & $\mathrm{PM}_{2.5}$ & 947 \\
\hline & & & Daegu & Attributable number of deaths & $\mathrm{PM}_{2.5}$ & 672 \\
\hline & & & Incheon & Attributable number of deaths & $\mathrm{PM}_{2.5}$ & 309 \\
\hline & & & Gwangju & Attributable number of deaths & $\mathrm{PM}_{2.5}$ & 657 \\
\hline & & & Daejeon & Attributable number of deaths & $\mathrm{PM}_{2.5}$ & 342 \\
\hline & & & Ulsan & Attributable number of deaths & $\mathrm{PM}_{2.5}$ & 222 \\
\hline & & & Sejong & Attributable number of deaths & $\mathrm{PM}_{2.5}$ & 49 \\
\hline
\end{tabular}

C-R functions applied by the authors. Specifically, Yorifuji, et al. ${ }^{35}$ and Leem, et al. ${ }^{37}$ used C-R functions for mortality derived from epidemiological studies conducted in the United States (U.S.), whereas Han, et al. ${ }^{36}$ used an IER function developed for the Global Burden of Disease 2010 and 2013. The C-R function derived from U.S. studies only accounted for a relatively low level of PM; thus, it may be inadequate for estimation of health impacts in Korea where exposure to higher concentrations of PM is observed. The IER function was developed by integrating various $\mathrm{C}-\mathrm{R}$ functions of other exposures, such as tobacco smoke and burning of indoor solid fuel, to fill the gap in exposure range. ${ }^{36}$ However, it remains uncertain whether the C-R function is comparable to the higher exposure range observed in Korea. Considering this, it is important to produce C-R functions using Korean data to accurately estimate the health impacts of exposure to air pollution.

As mentioned above, the effect of air pollution exposure can be divided into short-term and long-term effects. Typically, short-term effects are examined using time series and casecrossover studies, and long-term effects are investigated in cohort studies. The most recent time series study in Korea reported a $0.51 \%$ increase in mortality for each $10-\mu \mathrm{g} / \mathrm{m}^{3}$ increase in $\mathrm{PM}_{10}{ }^{16}$ This is comparable to the results of a recent meta-analysis of studies from East Asian cities, including Seoul and Incheon, which reported a $0.47 \%$ increase in total mortality for the same amount of increase in $\mathrm{PM}_{10}{ }^{40}$ Similarly, although we could not find health impact assessment studies regarding air pollutants other than $\mathrm{PM}$, we believe that previous epidemiological studies can provide relatively robust $\mathrm{C}-\mathrm{R}$ functions for $\mathrm{NO}_{2}$ and $\mathrm{SO}_{2}$ to estimate health impacts.

Previous studies have reported inconsistent associations between $\mathrm{O}_{3}$ exposure and mortality. Some published studies have reported a negative association, and the cause of this negative association has been an intriguing subject for additional analysis. One hypothesis is that the C-R function between $\mathrm{O}_{3}$ concentration and mortality is not linear. ${ }^{41}$ Time series analyses conducted in Korea and Japan support this hypothesis in short-term associations. ${ }^{42,43}$ However, such non-linearity has not been observed in other studies, ${ }^{44,45}$ and the shape of the C-R function between $\mathrm{O}_{3}$ concentration and acute mortality is still controversial. Nevertheless, studies analyzing the C-R function for long-term exposure of $\mathrm{O}_{3}$ and mortality consistently report no evidence of a threshold. ${ }^{46,47}$ However, these studies may not have accounted for lower concentrations of $\mathrm{O}_{3}$; this may be the reason for not observing a non-linear association, as the reported threshold of non-linear associations tends to 
be at lower concentrations. The negative association reported in a cohort study conducted by Kim, et al. ${ }^{18}$ may suggest the existence of a non-linear $\mathrm{C}$ - $\mathrm{R}$ function between long-term exposure to $\mathrm{O}_{3}$ and mortality because Korea has lower concentrations of $\mathrm{O}_{3}$ than the U.S. ${ }^{43}$ however, no analysis has been conducted using Korean data, as far as we know.

Among the two cohort studies on air pollution and mortality, one study examined the long-term health effects of $\mathrm{PM}_{2.5}$ exposure. Although it is a valuable addition to the current knowledge, the results of that study seem inconsistent with previous reports. For instance, Kim, et al. ${ }^{18}$ reported an $\mathrm{HR}$ of 1.32 for all-cause mortality for a $1-\mu \mathrm{g} / \mathrm{m}^{3}$ increment of $\mathrm{PM}_{2.5}$ in a cohort constructed using the National Health Insurance Service database, and a recent U.S. study analyzing a cohort constructed from a Medicare database reported an HR of 1.073 for a $10-\mu \mathrm{g} / \mathrm{m}^{3}$ increment of $\mathrm{PM}_{2.5 .}{ }^{47} \mathrm{Kim}$, et al. ${ }^{18}$ suggested possible differences in the effect and composition of $\mathrm{PM}_{2.5}$, genetic characteristics, and range of exposure between these studies, although we find a more than 30 -fold greater HR difficult to explain. The largest difference between these two studies was in exposure assessment. Kim, et al. ${ }^{18}$ linked the concentration measured at a fixed monitoring station to the addresses of participants, whereas Di, et al. ${ }^{47}$ used a model-based estimation of individual exposure. Another cohort study examined the long-term effect of $\mathrm{PM}_{10}$ exposure. ${ }^{17}$ Those authors reported similar effects for $\mathrm{PM}_{10}$ exposure, although the association was not statistically significant. However, this latter study applied an exposure assessment strategy, which could alleviate the effect of misclassification caused by participant mobility and exposure measurement at fixed monitoring stations.

Conventionally, air pollution studies use concentrations measured at fixed monitoring stations for exposure, which is an advantage for providing a large amount of data for a wide range of pollutants. However, data linked to study participants' addresses may not reflect individual exposure, especially when the mobility pattern of individuals is not accounted for. ${ }^{48}$ This limitation may lead to misclassification, which may have substantial implications for the interpretation of results. ${ }^{49} \mathrm{In}$ recent years, advanced sensor and modeling technologies have facilitated individual exposure measurement in air pollution studies with the use of personal sensors and various exposure models based on dispersion models, geographical information, and satellite images. ${ }^{48,50,51}$ Estimation of exposure using these methods in Korea has been reported recently, ${ }^{52}$ and these individual exposure estimation methods should be applied in future studies to reduce uncertainty.

In addition to observational studies, there have been many intervention studies on air pollution and its health effects. Recent intervention studies have explored the benefits of exposure reduction using devices, such as an air purifier ${ }^{53,54}$ and facemasks, ${ }^{55}$ in randomized controlled trials. The strength of intervention studies is two-fold: First, intervention studies may provide more robust evidence regarding the health effects of exposure to air pollution. Second, these trials may provide evidence regarding the effectiveness of personal measures that can be used to reduce the effects of air pollution. However, due to ethical and practical limitations, randomized controlled trials can only be applied to evaluate acute effects of exposure to air pollution. For instance, it may be unfeasible and unethical to design a study in which a portion of study participants are asked to wear facemasks for a long period (e.g., years). Causal modeling is a method that has been proposed to mitigate the shortcomings of observational studies without the need to conduct a randomized trial. This approach includes marginal structure modeling, instrumental variable analysis, and negative exposure control. ${ }^{56}$ The causal modeling approach provides associations that are free of confounding under certain assumptions, which can be interpreted as causal, similar to the results of a trial. To date, there had been reports on the causal associations of $\mathrm{PM}_{2.5}$, black carbon, and $\mathrm{NO}_{2}$ in various circumstances. ${ }^{57,58}$ Such experimental studies are necessary so as to correctly assess the effects of air pollution on health and to facilitate more effective interventions through which to reduce exposure and to mitigate the health effects of air pollution.

Finally, despite our best efforts to comprehensively summarize the study results regarding the health effects of air pollution exposure in Korea, it is possible that we did not compile a complete list of all relevant research, which should be considered a limitation of the present review.

\section{CONCLUSION}

In the present review, we presented epidemiological studies conducted in Korea examining the health effects of exposure to air pollution. For the past 2 decades, there has been a considerable accumulation of knowledge regarding air pollution and health in Korea. However, the present review highlights that additional studies, especially cohort and experimental studies, are needed to provide more robust and accurate evidence that can be used to promote evidence-based policymaking.

\section{ACKNOWLEDGEMENTS}

The present research was conducted by the research fund of Dankook University in 2016.

\section{AUTHOR CONTRIBUTIONS}

Conceptualization: S Bae, H Kwon. Data curation: S Bae. Formal analysis: S Bae. Funding acquisition: H Kwon. Investigation: S Bae, H Kwon. Methodology: S Bae, H Kwon. Project administration: H Kwon. Resources: S Bae, H Kwon. Software: S Bae, H Kwon. Supervision: H Kwon. Validation: S Bae, H Kwon. Visualization: S Bae, H Kwon. Writing-original draft: S Bae, H Kwon. Writing_review \& editing: S Bae, H Kwon. 


\section{ORCID iDs}

Sanghyuk Bae

https://orcid.org/0000-0002-4995-6543

Ho-jang Kwon https://orcid.org/0000-0003-3029-5674

\section{REFERENCES}

1. GBD 2016 Risk Factors Collaborators. Global, regional, and national comparative risk assessment of 84 behavioural, environmental and occupational, and metabolic risks or clusters of risks, 1990-2016: a systematic analysis for the Global Burden of Disease Study 2016. Lancet 2017;390:1345-422.

2. National Institute of Environmental Research. Annual report of air quality in Korea 2016. Incheon: National Institute of Environmental Research; 2017.

3. Anderson HR, Atkinson RW, Peacock JL, Marston L, Konstantinou K. Meta-analysis of time-series studies and panel studies of particulate matter $(\mathrm{PM})$ and ozone $\left(\mathrm{O}_{3}\right)$ : report of a WHO task group. Copenhagen: WHO Regional Office for Europe; 2004.

4. Wong CM, Vichit-Vadakan N, Kan H, Qian Z. Public Health and Air Pollution in Asia (PAPA): a multicity study of short-term effects of air pollution on mortality. Environ Health Perspect 2008;116: 1195-202.

5. Burnett RT, Pope CA 3rd, Ezzati M, Olives C, Lim SS, Mehta S, et al. An integrated risk function for estimating the global burden of disease attributable to ambient fine particulate matter exposure. Environ Health Perspect 2014;122:397-403.

6. Burnett R, Chen H, Szyszkowicz M, Fann N, Hubbell B, Pope CA 3rd, et al. Global estimates of mortality associated with long-term exposure to outdoor fine particulate matter. Proc Natl Acad Sci U S A 2018;115:9592-7.

7. Levy JI, Diez D, Dou Y, Barr CD, Dominici F. A meta-analysis and multisite time-series analysis of the differential toxicity of major fine particulate matter constituents. Am J Epidemiol 2012;175: 1091-9.

8. Baxter LK, Duvall RM, Sacks J. Examining the effects of air pollution composition on within region differences in $\mathrm{PM}_{2.5}$ mortality risk estimates. J Expo Sci Environ Epidemiol 2013;23:457-65.

9. Davis JA, Meng Q, Sacks JD, Dutton SJ, Wilson WE, Pinto JP. Regional variations in particulate matter composition and the ability of monitoring data to represent population exposures. Sci Total Environ 2011;409:5129-35.

10. Lee JT, Shin D, Chung Y. Air pollution and daily mortality in Seoul and Ulsan, Korea. Environ Health Perspect 1999;107:149-54.

11. Hong YC, Leem JH, Ha EH, Christiani DC. $\mathrm{PM}_{10}$ exposure, gaseous pollutants, and daily mortality in Inchon, South Korea. Environ Health Perspect 1999;107:873-8.

12. Lee JT, Schwartz J. Reanalysis of the effects of air pollution on daily mortality in Seoul, Korea: a case-crossover design. Environ Health Perspect 1999;107:633-6.

13. Hong YC, Leem JH, Ha EH. Air pollution and daily mortality in Inchon, Korea. J Korean Med Sci 1999;14:239-44.

14. Son JY, Lee JT, Kim H, Yi O, Bell ML. Susceptibility to air pollution effects on mortality in Seoul, Korea: a case-crossover analysis of individual-level effect modifiers. J Expo Sci Environ Epidemiol 2012;22:227-34.

15. Kim H, Kim Y, Hong YC. The lag-effect pattern in the relationship of particulate air pollution to daily mortality in Seoul, Korea. Int J Biometeorol 2003;48:25-30.

16. Kim SE, Honda Y, Hashizume M, Kan H, Lim YH, Lee H, et al. Seasonal analysis of the short-term effects of air pollution on daily mortality in Northeast Asia. Sci Total Environ 2017;576:850-7.
17. Kim OJ, Kim SY, Kim H. Association between long-term exposure to particulate matter air pollution and mortality in a South Korean National Cohort: comparison across different exposure assessment approaches. Int J Environ Res Public Health 2017;14: 1103.

18. Kim H, Kim J, Kim S, Kang SH, Kim HJ, Kim H, et al. Cardiovascular effects of long-terrm exposure to air pollution: a populationbased study with 900845 person-years of follow-up. J Am Heart Assoc 2017;6:e007170.

19. Kim C, Jung SH, Kang DR, Kim HC, Moon KT, Hur NW, et al. Ambient particulate matter as a risk factor for suicide. Am J Psychiatry 2010;167:1100-7.

20. Kwon HJ, Cho SH, Nyberg F, Pershagen G. Effects of ambient air pollution on daily mortality in a cohort of patients with congestive heart failure. Epidemiology 2001;12:413-9.

21. Hong YC, Lee JT, Kim H, Kwon HJ. Air pollution: a new risk factor in ischemic stroke mortality. Stroke 2002;33:2165-9.

22. Son JY, Cho YS, Lee JT. Effects of air pollution on postneonatal infant mortality among firstborn infants in Seoul, Korea: casecrossover and time-series analyses. Arch Environ Occup Health 2008;63:108-13.

23. Lee JT, Kim H, Song H, Hong YC, Cho YS, Shin SY, et al. Air pollution and asthma among children in Seoul, Korea. Epidemiology 2002;13:481-4.

24. Lee BE, Ha EH, Park HS, Kim H, Lee HJ, Lee YK, et al. [Air pollution and respiratory symptoms of school children in a panel study in Seoul]. J Prev Med Public Health 2005;38:465-72.

25. Son JY, Kim H, Lee JT, Kim SY. [Relationship between the exposure to ozone in Seoul and the childhood asthma-related hospital admissions according to the socioeconomic status]. J Prev Med Public Health 2006;39:81-6.

26. Kim BJ, Kwon JW, Seo JH, Kim HB, Lee SY, Park KS, et al. Association of ozone exposure with asthma, allergic rhinitis, and allergic sensitization. Ann Allergy Asthma Immunol 2011;107:214-9.

27. Kim BJ, Seo JH, Jung YH, Kim HY, Kwon JW, Kim HB, et al. Air pollution interacts with past episodes of bronchiolitis in the development of asthma. Allergy 2013;68:517-23.

28. Han MH, Yi HJ, Kim YS, Kim YS. Effect of seasonal and monthly variation in weather and air pollution factors on stroke incidence in Seoul, Korea. Stroke 2015;46:927-35.

29. Ha M, Hwang SS, Kang S, Park NW, Chang BU, Kim Y. Geographical correlations between indoor radon concentration and risks of lung cancer, non-Hodgkin's lymphoma, and leukemia during 19992008 in Korea. Int J Environ Res Public Health 2017;14:344.

30. Lamichhane DK, Kim HC, Choi CM, Shin MH, Shim YM, Leem $\mathrm{JH}$, et al. Lung cancer risk and residential exposure to air pollution: a Korean population-based case-control study. Yonsei Med J 2017;58:1111-8.

31. Lim YH, Kim H, Kim JH, Bae S, Park HY, Hong YC. Air pollution and symptoms of depression in elderly adults. Environ Health Perspect 2012;120:1023-8.

32. Kim KN, Lim YH, Bae HJ, Kim M, Jung K, Hong YC. Long-term fine particulate matter exposure and major depressive disorder in a community-based urban cohort. Environ Health Perspect 2016; 124:1547-53.

33. Seo JH, Ha EH, Kim OJ, Kim BM, Park HS, Leem JH, et al. [Environmental health surveillance of low birth weight in Seoul using air monitoring and birth data]. J Prev Med Public Health 2007;40: 363-70.

34. Seo JH, Leem JH, Ha EH, Kim OJ, Kim BM, Lee JY, et al. Population-attributable risk of low birthweight related to $\mathrm{PM}_{10}$ pollution in seven Korean cities. Paediatr Perinat Epidemiol 2010;24:140-8.

35. Yorifuji T, Bae S, Kashima S, Tsuda T, Doi H, Honda Y, et al. Health 
impact assessment of $\mathrm{PM}_{10}$ and $\mathrm{PM}_{2.5}$ in 27 Southeast and East Asian cities. J Occup Environ Med 2015;57:751-6.

36. Han C, Kim S, Lim YH, Bae HJ, Hong YC. Spatial and temporal trends of number of deaths attributable to ambient $\mathrm{PM}_{2.5}$ in the Korea. J Korean Med Sci 2018;33:e193.

37. Leem JH, Kim ST, Kim HC. Public-health impact of outdoor air pollution for 2nd air pollution management policy in Seoul metropolitan area, Korea. Ann Occup Environ Med 2015;27:7.

38. Yoon SJ, Kim HS, Ha J, Kim EJ. Measuring the environmental burden of disease in South Korea: a population-based study. Int J Environ Res Public Health 2015;12:7938-48.

39. Künzli N, Kaiser R, Medina S, Studnicka M, Chanel O, Filliger P, et al. Public-health impact of outdoor and traffic-related air pollution: a European assessment. Lancet 2000;356:795-801.

40. Park HY, Bae S, Hong YC. PM $_{10}$ exposure and non-accidental mortality in Asian populations: a meta-analysis of time-series and case-crossover studies. J Prev Med Public Health 2013;46:10-8.

41. Moolgavkar SH, McClellan RO, Dewanji A, Turim J, Luebeck EG, Edwards M. Time-series analyses of air pollution and mortality in the United States: a subsampling approach. Environ Health Perspect 2013;121:73-8.

42. Kim SY, Lee JT, Hong YC, Ahn KJ, Kim H. Determining the threshold effect of ozone on daily mortality: an analysis of ozone and mortality in Seoul, Korea, 1995-1999. Environ Res 2004;94:113-9.

43. Bae S, Lim YH, Kashima S, Yorifuji T, Honda Y, Kim H, et al. Nonlinear concentration-response relationships between ambient ozone and daily mortality. PLoS One 2015;10:e0129423.

44. Bell ML, Peng RD, Dominici F. The exposure-response curve for ozone and risk of mortality and the adequacy of current ozone regulations. Environ Health Perspect 2006;114:532-6.

45. Atkinson RW, Yu D, Armstrong BG, Pattenden S, Wilkinson P, Doherty RM, et al. Concentration-response function for ozone and daily mortality: results from five urban and five rural U.K. populations. Environ Health Perspect 2012;120:1411-7.

46. Jerrett M, Burnett RT, Pope CA 3rd, Ito K, Thurston G, Krewski D, et al. Long-term ozone exposure and mortality. N Engl J Med 2009; 360:1085-95.

47. Di Q, Wang Y, Zanobetti A, Wang Y, Koutrakis P, Choirat C, et al. Air pollution and mortality in the medicare population. N Engl J Med 2017;376:2513-22.

48. Steinle S, Reis S, Sabel CE. Quantifying human exposure to air pollution--moving from static monitoring to spatio-temporally resolved personal exposure assessment. Sci Total Environ 2013;443: 184-93.

49. Zeger SL, Thomas D, Dominici F, Samet JM, Schwartz J, Dockery D, et al. Exposure measurement error in time-series studies of air pollution: concepts and consequences. Environ Health Perspect 2000;108:419-26.

50. Zou B, Wilson JG, Zhan FB, Zeng Y. Air pollution exposure assessment methods utilized in epidemiological studies. J Environ Monit 2009;11:475-90.

51. van Donkelaar A, Martin RV, Brauer M, Boys BL. Use of satellite observations for long-term exposure assessment of global concentrations of fine particulate matter. Environ Health Perspect 2015; 123:135-43.

52. Kim SY, Song I. National-scale exposure prediction for long-term concentrations of particulate matter and nitrogen dioxide in South Korea. Environ Pollut 2017;226:21-9.

53. Li H, Cai J, Chen R, Zhao Z, Ying Z, Wang L, et al. Particulate matter exposure and stress hormone levels: a randomized, double-blind, crossover trial of air purification. Circulation 2017;136:618-27.

54. Morishita M, Adar SD, D'Souza J, Ziemba RA, Bard RL, Spino C, et al. Effect of portable air filtration systems on personal exposure to fine particulate matter and blood pressure among residents in a low-income senior facility: a randomized clinical trial. JAMA Intern Med 2018;178:1350-7.

55. Guan T, Hu S, Han Y, Wang R, Zhu Q, Hu Y, et al. The effects of facemasks on airway inflammation and endothelial dysfunction in healthy young adults: a double-blind, randomized, controlled crossover study. Part Fibre Toxicol 2018;15:30.

56. Schwartz J, Austin E, Bind MA, Zanobetti A, Koutrakis P. Estimating causal associations of fine particles with daily deaths in Boston. Am J Epidemiol 2015;182:644-50.

57. Schwartz J, Bind MA, Koutrakis P. Estimating causal effects of local air pollution on daily deaths: effect of low levels. Environ Health Perspect 2017;125:23-9.

58. Schwartz J, Fong K, Zanobetti A. A national multicity analysis of the causal effect of local pollution, $\mathrm{NO}_{2}$, and $\mathrm{PM}_{2.5}$ on mortality. Environ Health Perspect 2018;126:087004.

59. Lee JT, Kim H, Hong YC, Kwon HJ, Schwartz J, Christiani DC. Air pollution and daily mortality in seven major cities of Korea, 19911997. Environ Res 2000;84:247-54.

60. Hong YC, Lee JT, Kim H, Ha EH, Schwartz J, Christiani DC. Effects of air pollutants on acute stroke mortality. Environ Health Perspect 2002;110:187-91.

61. Ha EH, Lee JT, Kim H, Hong YC, Lee BE, Park HS, et al. Infant susceptibility of mortality to air pollution in Seoul, South Korea. Pediatrics 2003;111:284-90.

62. Kim H, Lee JT, Hong YC, Yi SM, Kim Y. Evaluating the effect of daily $\mathrm{PM}_{10}$ variation on mortality. Inhal Toxicol 2004;16 Suppl $1: 55-8$.

63. Lee JT, Son JY, Cho YS. A comparison of mortality related to urban air particles between periods with Asian dust days and without Asian dust days in Seoul, Korea, 2000-2004. Environ Res 2007;105: 409-13.

64. Cho YS, Lee JT, Jung CH, Chun YS, Kim YS. Relationship between particulate matter measured by optical particle counter and mortality in Seoul, Korea, during 2001. J Environ Health 2008;71:3743.

65. Park AK, Hong YC, Kim H. Effect of changes in season and temperature on mortality associated with air pollution in Seoul, Korea. J Epidemiol Community Health 2011;65:368-75.

66. Son JY, Bell ML, Lee JT. Survival analysis of long-term exposure to different sizes of airborne particulate matter and risk of infant mortality using a birth cohort in Seoul, Korea. Environ Health Perspect 2011;119:725-30.

67. Heo J, Schauer JJ, Yi O, Paek D, Kim H, Yi SM. Fine particle air pollution and mortality: importance of specific sources and chemical species. Epidemiology 2014;25:379-88.

68. Lim YR, Bae HJ, Lim YH, Yu S, Kim GB, Cho YS. Spatial analysis of $\mathrm{PM}_{10}$ and cardiovascular mortality in the Seoul metropolitan area. Environ Health Toxicol 2014;29:e2014005.

69. Ha KH, Cho J, Cho SK, Kim C, Shin DC. Air pollution and unintentional injury deaths in South Korea. Environ Sci Pollut Res Int 2015;22:7873-81.

70. Kim SE, Bell ML, Hashizume M, Honda Y, Kan H, Kim H. Associations between mortality and prolonged exposure to elevated particulate matter concentrations in East Asia. Environ Int 2018;110: 88-94.

71. Lee H, Myung W, Kim SE, Kim DK, Kim H. Ambient air pollution and completed suicide in 26 South Korean cities: effect modification by demographic and socioeconomic factors. Sci Total Environ 2018;639:944-51.

72. Lee JT, Son JY, Cho YS. Benefits of mitigated ambient air quality due to transportation control on childhood asthma hospitalization during the 2002 summer Asian games in Busan, Korea. J Air 
Waste Manag Assoc 2007;57:968-73.

73. Lee JT, Son JY, Kim H, Kim SY. Effect of air pollution on asthma-related hospital admissions for children by socioeconomic status associated with area of residence. Arch Environ Occup Health 2006; 61:123-30.

74. Moon JS, Kim YS, Kim JH, Son BS, Kim DS, Yang W. Respiratory health effects among schoolchildren and their relationship to air pollutants in Korea. Int J Environ Health Res 2009;19:31-48.

75. Yi O, Hong YC, Kim H. Seasonal effect of $\mathrm{PM}_{10}$ concentrations on mortality and morbidity in Seoul, Korea: a temperature-matched case-crossover analysis. Environ Res 2010;110:89-95.

76. Kim JH, Hong YC. GSTM1, GSTT1, and GSTP1 polymorphisms and associations between air pollutants and markers of insulin resistance in elderly Koreans. Environ Health Perspect 2012;120: 1378-84.

77. Kim HH, Lee CS, Jeon JM, Yu SD, Lee CW, Park JH, et al. Analysis of the association between air pollution and allergic diseases exposure from nearby sources of ambient air pollution within elementary school zones in four Korean cities. Environ Sci Pollut Res Int 2013;20:4831-46.

78. Han SS, Kim S, Choi Y, Kim S, Kim YS. Air pollution and hemorrhagic fever with renal syndrome in South Korea: an ecological correlation study. BMC Public Health 2013;13:347.

79. Son JY, Lee JT, Park YH, Bell ML. Short-term effects of air pollution on hospital admissions in Korea. Epidemiology 2013;24:54554.

80. Park M, Luo S, Kwon J, Stock TH, Delclos G, Kim H, et al. Effects of air pollution on asthma hospitalization rates in different age groups in metropolitan cities of Korea. Air Qual Atmos Health 2013;6:54351.

81. Kim E, Park H, Hong YC, Ha M, Kim Y, Kim BN, et al. Prenatal exposure to $\mathrm{PM}_{10}$ and $\mathrm{NO}_{2}$ and children's neurodevelopment from birth to 24 months of age: mothers and Children's Environmental Health (MOCEH) study. Sci Total Environ 2014;481:439-45.

82. Hwang SS, Kang S, Lee JY, Lee JS, Kim HJ, Han SK, et al. Impact of outdoor air pollution on the incidence of tuberculosis in the Seoul metropolitan area, South Korea. Korean J Intern Med 2014;29:18390.

83. Kim J, Kim H, Kweon J. Hourly differences in air pollution on the risk of asthma exacerbation. Environ Pollut 2015;203:15-21.

84. Jang JH, Lee JH, Je MK, Cho MJ, Bae YM, Son HS, et al. Correlations between the incidence of national notifiable infectious diseases and public open data, including meteorological factors and medical facility resources. J Prev Med Public Health 2015;48:20315.

85. Shim SR, Kim JH, Song YS, Lee WJ. Association between air pollution and benign prostatic hyperplasia: an ecological study. Arch Environ Occup Health 2016;71:289-92.

86. Kang SH, Heo J, Oh IY, Kim J, Lim WH, Cho Y, et al. Ambient air pollution and out-of-hospital cardiac arrest. Int J Cardiol 2016; 203:1086-92.

87. Kim J, Han Y, Seo SC, Lee JY, Choi J, Kim KH, et al. Association of carbon monoxide levels with allergic diseases in children. Allergy Asthma Proc 2016;37:e1-7.

88. Kim HH, Lee CS, Yu SD, Lee JS, Chang JY, Jeon JM, et al. Nearroad exposure and impact of air pollution on allergic diseases in elementary school children: a cross-sectional study. Yonsei Med J 2016;57:698-713.

89. Han MH, Yi HJ, Ko Y, Kim YS, Lee YJ. Association between hemorrhagic stroke occurrence and meteorological factors and pollutants. BMC Neurol 2016;16:59.

90. Lee WH, Choo JY, Son JY, Kim H. Association between long-term exposure to air pollutants and prevalence of cardiovascular disease in 108 South Korean communities in 2008-2010: a cross-sectional study. Sci Total Environ 2016;565:271-8.

91. Lee KW, Choi YH, Hwang SH, Paik HJ, Kim MK, Wee WR, et al. Outdoor air pollution and pterygium in Korea. J Korean Med Sci 2017;32:143-50.

92. Chung JW, Bang OY, Ahn K, Park SS, Park TH, Kim JG, et al. Air pollution is associated with ischemic stroke via cardiogenic embolism. Stroke 2017;48:17-23.

93. Kim J, Kim H, Lim D, Lee YK, Kim JH. Effects of indoor air pollutants on atopic dermatitis. Int J Environ Res Public Health 2016;13: 1220.

94. Hwang SH, Lee JY, Yi SM, Kim H. Associations of particulate matter and its components with emergency room visits for cardiovascular and respiratory diseases. PLoS One 2017;12:e0183224.

95. Yi SJ, Shon C, Min KD, Kim HC, Leem JH, Kwon HJ, et al. Association between exposure to traffic-related air pollution and prevalence of allergic diseases in children, Seoul, Korea. Biomed Res Int 2017;2017:4216107.

96. Lamichhane DK, Ryu J, Leem JH, Ha M, Hong YC, Park H, et al. Air pollution exposure during pregnancy and ultrasound and birth measures of fetal growth: a prospective cohort study in Korea. Sci Total Environ 2018;619-620:834-41. 